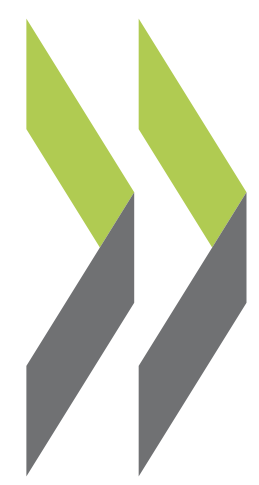

OECD Economics Department Working Papers No. 1553

Objectives and challenges in the implementation of a universal pension system in France 


\section{ECONOMICS DEPARTMENT}

\section{OBJECTIVES AND CHALLENGES IN THE IMPLEMENTATION OF A UNIVERSAL PENSION SYSTEM IN FRANCE}

\section{ECONOMICS DEPARTMENT WORKING PAPERS No. 1553}

By Hervé Boulhol

OECD Working Papers should not be reported as representing the official views of the OECD or of its member countries. The opinions expressed and arguments employed are those of the author(s).

Authorised for publication by Isabell Koske, Deputy Director, Country Studies Branch, Economics Department.

All Economics Department Working Papers are available at www.oecd.org/eco/workingpapers.

JT03447800 
OECD Working Papers should not be reported as representing the official views of the OECD or of its member countries. The opinions expressed and arguments employed are those of the author(s).

Working Papers describe preliminary results or research in progress by the author(s) and are published to stimulate discussion on a broad range of issues on which the OECD works.

Comments on Working Papers are welcomed, and may be sent to OECD Economics Department, 2 rue André Pascal, 75775 Paris Cedex 16, France, or by e-mail to eco.contact@oecd.org.

All Economics Department Working Papers are available at www.oecd.org/eco/workingpapers.

This document and any map included herein are without prejudice to the status of or sovereignty over any territory, to the delimitation of international frontiers and boundaries and to the name of any territory, city or area.

The statistical data for Israel are supplied by and under the responsibility of the relevant Israeli authorities. The use of such data by the OECD is without prejudice to the status of the Golan Heights, East Jerusalem and Israeli settlements in the West Bank under the terms of international law.

On 25 May 2018, the OECD Council invited Colombia to become a Member. At the time of preparation the deposit of Colombia's instrument of accession to the OECD Convention was pending and therefore Colombia does not appear in the list of OECD Members and is not included in the OECD zone aggregates.

\section{(C) OECD (2019)}

You can copy, download or print OECD content for your own use, and you can include excerpts from OECD publications, databases and multimedia products in your own documents, presentations, blogs, websites and teaching materials, provided that suitable acknowledgment of OECD as source and copyright owner is given. All requests for commercial use and translation rights should be submitted to rights@oecd.org 


\section{ABSTRACT/RESUMÉ \\ Objectives and challenges in the implementation of a universal pension system in France}

The mission of the French High Commission for Pension Reform is to prepare the reform introducing a universal pension points system in France. This paper explains why implementing a universal points system in France would increase transparency, reduce inequality and generate efficiency gains for the whole economy. It documents the experience of OECD countries which have opted for a points or a notional defined contribution (NDC) schemes, and provides a technical framework to compare defined benefit, points and NDC pension systems. The paper discusses some key issues related to the main parameters of the new system. While it can include a wide range of redistribution schemes depending on political choices, indexation rules should be designed in a way that maximises, as much as possible, the rates of return on pension contributions within a pay-as-you-go system while ensuring financial sustainability and accounting for changes in life expectancy. This implies that the value of the point would vary at the individual level depending on the cohort and the effective age of retirement based on actuarial principles. No country having a points system currently uses age-cohort point values, and France could be the first one to introduce such an innovation.

This Working Paper relates to the 2019 OECD Economic Survey of France (http://www.oecd.org/economy/surveys/france-economic-snapshot)

JEL codes: H53, H55, J11, J26.

Keywords: pensions, reform, France, redistribution, life expectancy

$* * * * * * * * * *$

\section{Objectifs et enjeux de la mise en place d'un système de retraite universel en France}

Le Haut-commissariat français à la réforme des retraites a pour mission de préparer la réforme introduisant un système universel de retraite par points en France. Ce document de travail explique pourquoi la mise en place en France d'un système universel par points augmenterait la transparence, réduirait les inégalités et engendrerait des gains d'efficacité pour l'ensemble de l'économie. Il documente l'expérience des pays de l'OCDE qui ont opté pour un régime par points ou en comptes notionnels à cotisations définies et fournit un cadre technique permettant de comparer les systèmes de retraite à prestations définies, par points et en comptes notionnels. Le document aborde certaines questions clés liées aux paramètres principaux du nouveau système. Alors qu'il peut inclure une large gamme d'instruments redistributifs selon les choix politiques qui sont faits, les règles d'indexation doivent être conçues de manière à maximiser, autant que possible, le rendement des cotisations d'un système par répartition, tout en garantissant la viabilité financière et en prenant en compte les évolutions de l'espérance de vie. Cela implique que la valeur du point varie au niveau individuel en fonction de chaque cohorte et de chaque âge effectif de la retraite sur la base des principes actuariels. À l'heure actuelle, aucun pays n'utilise des valeurs de point différenciées selon l'âge et la cohorte, et la France pourrait être le premier pays à introduire cette innovation.

Ce Document de travail se rapporte à l'Étude économique de l'OCDE de la France 2019

(http://www.oecd.org/fr/economie/etudes/economie-de-la-france-en-un-coup-d-oeil/)

Codes JEL: H53, H55, J11, J26.

Mots clés : pensions, réforme, France, redistribution, espérance de vie 


\section{Table of contents}

Objectives and challenges in the implementation of a universal pension system in France 5

Introduction 5

1. Why a universal pension system would be a big move forward for France..................................... 7

1.1. Simplification, equity, modernisation, efficiency ................................................................... 7

1.2. Public- and private-sector pensions in the OECD: Toward a unified system............................. 9

2. How have other countries managed the transition .................................................................. 13

2.1. Germany: Introduction of points in the private sector was just a formal shift............................ 14

2.2. Sweden: Where NDC started at the core of the public pension system..................................... 15

2.3. Norway: Building on the Swedish model with flexible financial management.......................... 16

2.4. CEECs: Fast transitions amid the transformation of the economies........................................ 17

2.5. Italy: Long transition as past entitlements were not converted................................................ 19

2.6. Belgium: Proposed switch to a points system has been delayed ............................................. 21

3. To what extent are DB, points and NDC inter-related within PAYGO ......................................... 21

4. Key parameters of the new system.................................................................................................................. 28

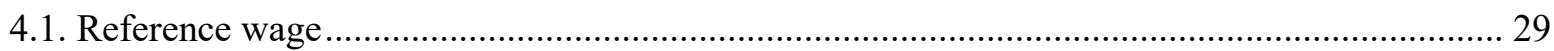

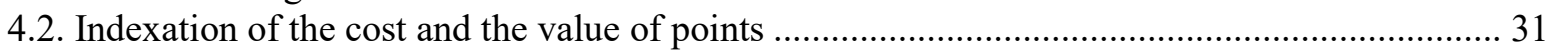

Adjustments to wage growth, employment growth and longevity gains .................................... 31

Comparison with countries having a points or NDC scheme.................................................... 34

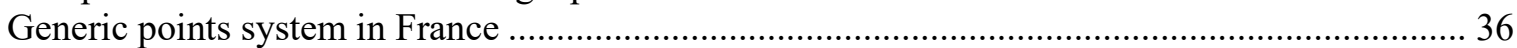

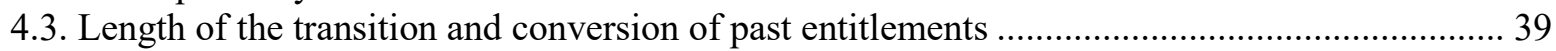

4.4. Would the reform imply a less redistributive pension system? ................................................ 39

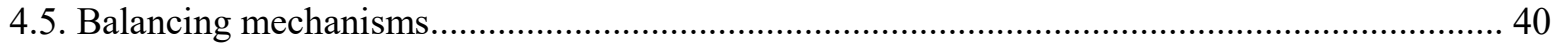

5. Conclusion ................................................................................................................................................................. 44

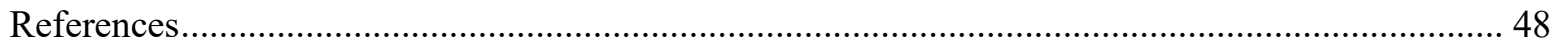

\section{Figures}

Figure 1.1. High relative income and low poverty rate among older people in France 7

\section{Boxes}

Box 4.1. The mechanics of the German points system 


\title{
Objectives and challenges in the implementation of a universal pension system in France
}

\author{
By Hervé Boulhol ${ }^{1}$
}

\section{Introduction}

1. The French government created the High Commission for Pension Reform in September 2017. Its mission is to prepare the reform introducing a universal pension points system: by organising discussions among the main stakeholders in the pension area; and, by coordinating the reform at the inter-ministerial level, the new pension legislation and rules as well as the implementation of the new system. Several OECD countries have a points system, which is pay-as-you-go (PAYGO): contributions are used to purchase points, and at retirement the sum of pension points is multiplied by the point value and converted into a regular pension payment.

2. In November 2018, the High Commission disclosed the main lines of action of the reform. It will:

- be based on common rules for contributions and the calculation of pension entitlements.

- drastically simplify the current system.

- ensure financial sustainability by reducing the sensitivity of financial balances to economic and demographic trends and short-term shocks.

- be better adapted to changes that affect employment and the economy more broadly.

Greater details provided in November 2018 are discussed in Section 4.

3. The current French pension system offers good protection. Mandatory schemes in France are PAYGO, mostly defined benefit, and voluntary funded pensions play a limited role as many saving instruments already benefit from tax incentives and target long-term savings. Replacement rates for average-wage workers are well above the OECD average (OECD, 2017). The minimum pension scheme (minimum contributif) and non-contributory benefits (Allocation de Solidarité aux Personnes Agées, ASPA) help achieve one of the lowest old-age poverty rates in the OECD. While there is little redistribution embedded in

1. The author, member of the Directorate of Employment, Labour and Social Affairs of the OECD, is grateful to various colleagues who provided valuable inputs: Boele Bonthuis, Christian Geppert, Marius Lüske, Andrew Reilly, and, in particular, Maciej Lis, as well as Sylvie Ricordeau for technical assistance. Very useful comments from numerous officials have contributed to upgrading this working paper, including from Pierre Beynet and David Law (OECD Economics Department), Arne Magnus Christensen (Norwegian Ministry of Labour and Social Affairs), Gijs Dekkers and Hans Peeters (Belgian Federal Planning Bureau), Kristoffer Lundberg (Swedish Ministry of Health and Social Affairs), Monika Queisser (OECD Directorate of Employment, Labour and Social Affairs), Carmelo Zizzo (French Ministry of Economy and Finance) and several officials from the French Pensions Advisory Council (COR). 
the pension system among private-sector workers with stable and full careers, first-tier pensions and instruments such as pension credits for periods of unemployment and childcare substantially reduce old-age inequality.

4. However the pension system is deeply fragmented and its structure is overly complex, which generate large inefficiencies. While information about accumulated pension rights has improved recently, misunderstandings about entitlements create uncertainty, prevent people from taking the appropriate consumption-saving decisions over the life-cycle and are detrimental to the trust in the system. The objective of the planned reform is to simplify the system substantially, reduce inequalities in the rules used to compute benefits, facilitate labour mobility and improve its management.

5. This working paper is organised as follows. Section 1 explains why implementing a universal points system in France would be an important move forward, increasing transparency, reducing inequality and generating efficiency gains for the whole economy. Section 2 documents the experience of OECD countries which have opted for a points or a notional defined contribution (NDC) schemes. Section 3 provides a technical framework to compare defined benefit, points and NDC schemes. It extends previous similar comparison exercises undertaken in the static case to the dynamic case driven by changes in mortality rates. Section 4 discusses some key issues related to the main parameters of the new system. Section 5 concludes. 


\section{Why a universal pension system would be a big move forward for France}

\subsection{Simplification, equity, modernisation, efficiency}

6. The French pension system provides an effective social protection for current retirees, translating into high average relative income and low relative poverty among the elderly in international comparison (Figure 1). Moreover, in line with exiting the labour market at relatively young ages, the retirement period is typically very long in France: remaining life expectancy at the average effective age of labour market exit is record high, 5 years larger than in the OECD on average (Figure 2). Longer life expectancy at age $60-$ which is great achievement in France, raising total welfare - contributes by less than onethird to this 5-year difference.

Figure 1.1. High relative income and low poverty rate among older people in France

2016 or latest

Panel A: Average income of people over 65 as $\%$ of average income of total population

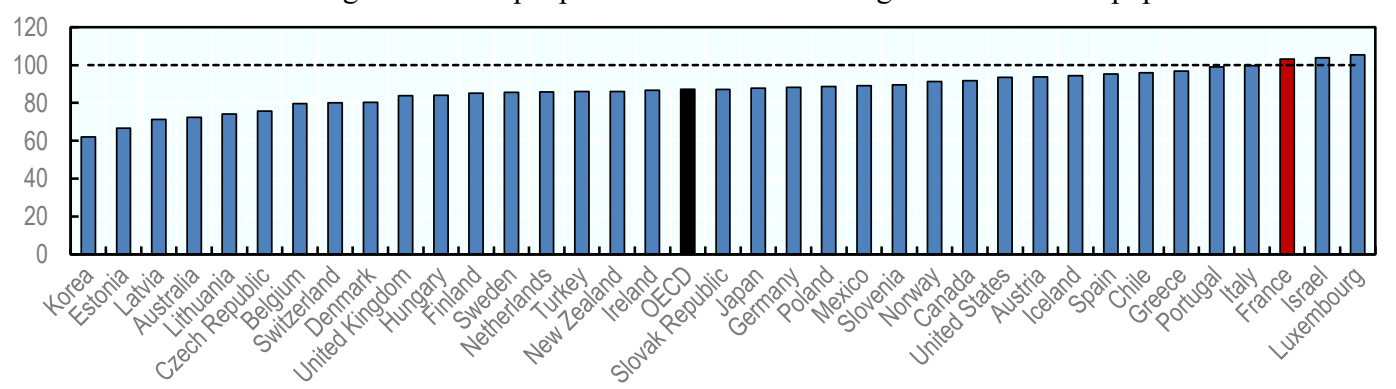

Panel B: Income poverty rate of people over 65 (disposable income below $50 \%$ of median income)

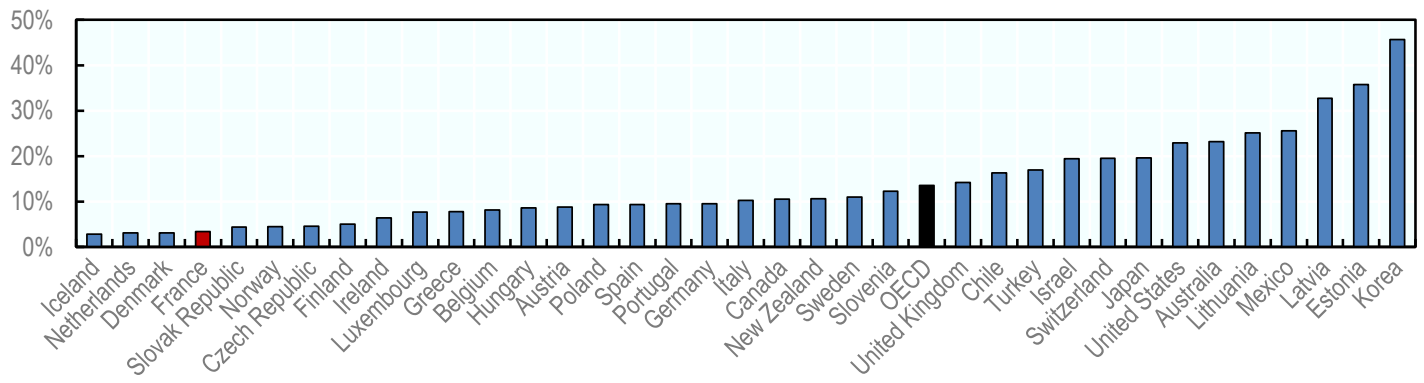

Source: OECD Income Distribution Database.

7. Good protection for long periods of retirement is thus achieved by relying on substantial financial resources, and only Italy and Greece spend more than France on oldage pensions as a percentage of GDP (OECD, 2017). However, neither raising retirement ages nor lowering pension expenditures more generally are among the direct objectives of the planned pension reform towards a universal regime. Changes in legal retirement ages are typically very sensitive such that placing these changes at the policy agenda might derail the reform process. Attention should therefore focus on the main objectives of this important reform.

8. Reducing the complexity of the French system to enhance economic performance is the prime goal. There are 42 mandatory pension schemes having very different rules. On 
average each individual has currently contributed to more than 3 regimes which do not add up in a straightforward way, with one-third having entitlements in more than 4 regimes. $^{2}$

Figure 2. Remaining life expectancy at the average effective labour market exit age years

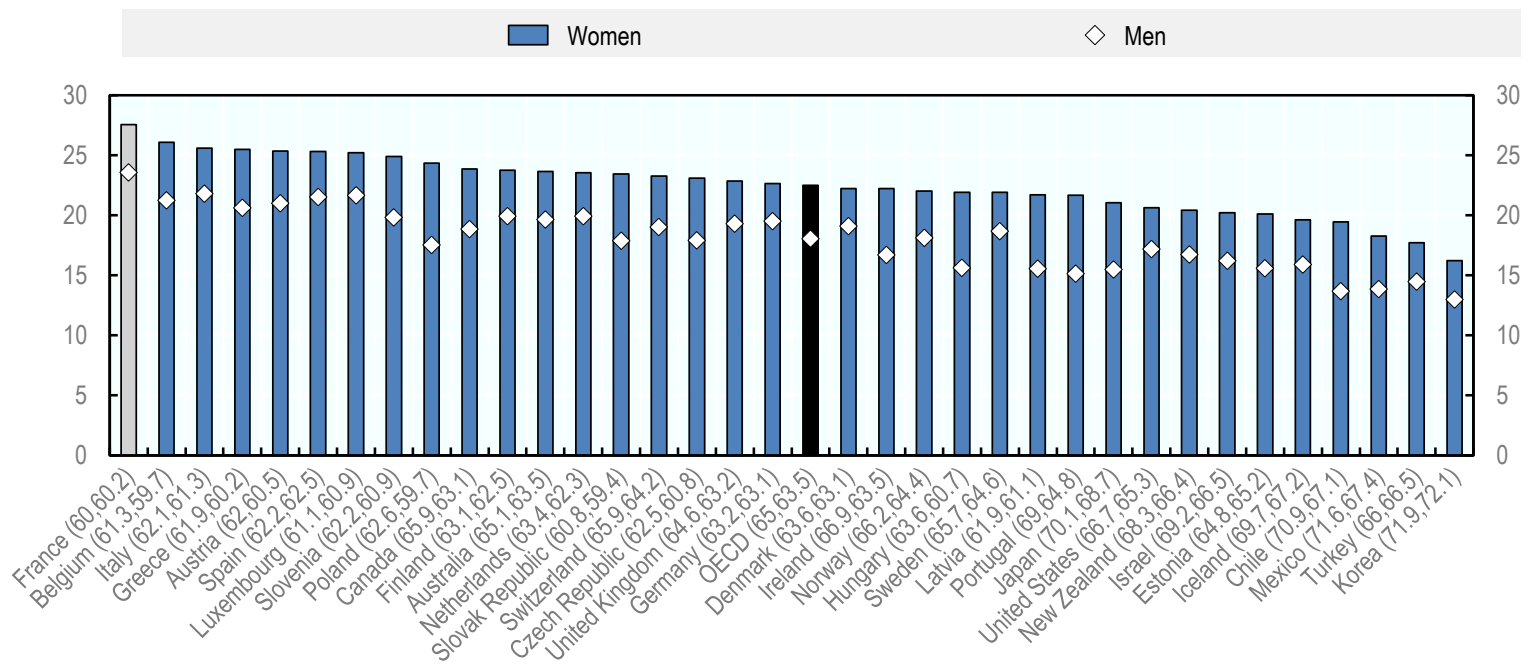

Note: Numbers in parenthesis on the $x$ axis designate the average effective age of labour market exit for men and women.

Source: Indicator 5.10 in OECD (2017).

9. The fragmentation of the system also implies substantial differences in the treatment of workers in the private sector, the public sector and those covered by numerous special regimes. Large inequalities result from differences, despite some recent convergence, in the rules used to compute benefits, including those applying to survivor pensions. Given intricate rules to be combined across so many different regimes, these differences also create a suspicion that other workers in other sectors are better treated. In turn, this suspicion fuels the motivation to defend one's own interests and complicates the implementation of policies to improve the system and reduce unequal treatment. Yet, a large majority of French citizens seems to be supportive of a pension reform that will simplify and unify the way contributions generate entitlements. ${ }^{3}$ Moreover, even though reducing expenditures is not the objective of the reform, simplifying and unifying the system could generate savings over time by reducing its administrative costs.

10. Due to the complex interactions between the rules of the various schemes, issues raised by workers affiliated to different regimes - so-called "polypensionnés" - often become serious obstacles to the needed reforms that modify some parameters in some schemes. These interactions are also a serious hurdle for the overall management of the system as the envisaged policy measures only have partial effects. Yet, these partial reforms carry some political cost and their needed recurrence gives the impression that pensions require some endless adjustments, harming confidence in the stability of the overall system.

2. Generations born between 1949 and 1992, source GIP union Retraite.

3. https://elabe.fr/systeme-retraite. 
11. One example is given by the reform of the mandatory occupational schemes, which started to apply in January 2019. France is unusual as it has two mandatory public (national accounts definition) PAYGO pension schemes covering private-sector workers: a general defined benefit (DB) scheme managed by the State and a points scheme managed by social partners, together representing about $70 \%$ of total pensions paid. ${ }^{4}$ In October 2015 , social partners decided to reform their points schemes in order to improve its financial sustainability. Measures taken have included a $10 \%$ temporary penalty if the contribution period to get a full pension from the general DB scheme (42 years for the 1963 birth cohort increasing to 43 years for those born in 1973) is not extended by at least one year. This temporary penalty is applied during at most 3 years or until the age of 67 , and does not apply to those who retire with a penalty from the general scheme.

12. While efforts to ensure financial sustainability and provide incentives to work longer are welcome, this reform highlights coordination problems. Meeting conditions for a full pension in the main scheme (régime général) is not necessarily sufficient to access a full pension in the mandatory complementary PAYGO scheme. Beyond the administrative cost, the duality of mandatory public schemes creates some confusion in both the eligibility period and the level of benefit people can expect, which is amplified by the last reform.

13. The overall complexity also creates serious obstacles in the understanding contributors have of their entitlements, and therefore in their ability to anticipate correctly their retirement income and take the retirement decisions that fit best their own preferences. Given standard aversion to risks, chosen labour mobility might be limited as a result, which impairs the efficient matching of labour supply across firms and sectors. Such a fragmented pension landscape is ill-suited to the labour market needs of a modern open economy.

14. The multiplication of special, mandatory occupational pension schemes is often reminiscent of the historical construction of pension systems in many countries. In France, state involvement at a later stage added a layer rather than replacing existing schemes. Moreover, in the public sector, pension schemes in many countries were often part of broader reforms of the civil service aimed at ensuring professionalism and independence of employees from outside influence (OECD, 2016).

15. One historical reason for a preferential treatment could have resulted from the need to attract workers in the civil service, a need that has vanished over time. These views also refer to the career being considered a job for life; in the absence of mobility civil service pensions in particular were therefore best organised in a stand-alone system. A job for life is a thing of the past. In short, the rationale for special pension arrangements are less relevant now that national pension systems are in place.

\subsection{Public- and private-sector pensions in the OECD: Toward a unified system}

16. This part focuses on the differences in the pension schemes covering private-sector workers and civil servants from the central government, as a way to illustrate the specificities of the French system. OECD countries can be classified into four categories (Table 1).

17. In half of OECD countries, all employees are covered under the same mandatory schemes at least for new labour market entrants (first category). Half of these countries fully aligned the schemes over the last two decades. This includes Japan (2016), New

4. The other $30 \%$ come from special regimes including those covering civil servants. 
Zealand (2007) and Southern European Countries (Greece and Spain, 2011; Portugal, 2006; and, Italy, 1995/2008). In many countries, civil-servant schemes are in a period of transition: new entrants are covered under the new system while those with many years of service remain in the old scheme. In the second broad category, Finland, Luxembourg, the Netherlands and Sweden have technically separate schemes for civil servants, but with similar benefits to those covering private-sector workers. This means that the schemes are basically identical but managed by different administrations.

Table 1. Institutional arrangements for civil service pensions vs private-sector workers

\begin{tabular}{llll}
\hline Fully integrated & Separate but similar benefits & Fully integrated with top-up & Entirely separate \\
\hline Chile (1981) & Finland (1995) & Australia & Belgium \\
Czech Republic & Luxembourg (1999) & Austria (2004,2009) & France \\
Estonia & Netherlands & Canada & Germany \\
Greece (2011) & Sweden & Denmark & Korea \\
Hungary & & Iceland & \\
Israel (2002) & & Ireland (1995) & \\
Italy (1995/2008) & & Mexico (2007) & \\
Japan (2015) & Norway & \\
Latvia & United Kingdom & \\
Lithuania & United States (1984) & \\
New Zealand (2007) & & & \\
Poland & & \\
Portugal (2006) & & & \\
Slovak Republic & & & \\
Slovenia & & \\
Spain (2011) & & \\
Switzerland & & \\
Turkey (2006) & & & \\
\hline
\end{tabular}

Note: The years in brackets refer to the date from which newly hired civil servants are no longer covered by an entirely separate scheme, but are rather in the fully integrated private sector scheme or have a top-up. For Italy new civil servants were covered by the private sector scheme from 1995 onwards, while in 2008 future contributions for all civil servants were under the private sector rules. For Austria the pension was fully integrated from 2004 but an additional top-up was introduced in 2009. For Finland the unifying process began in 1995, before which there was more of a top-up element to the system. All countries without a date have been in that particular category for at least the last 35 years (OECD, 2016).

18. Another ten countries have a top-up component for civil servants above and beyond the mandatory schemes that exist for private-sector workers. For example, in the United Kingdom all workers are covered by the new state pension, which is the only mandatory component; civil servants have a mandatory occupational pension as a top-up whereas private-sector workers can choose to participate in the new automatic enrolment scheme as occupational pensions are not mandatory (OECD, 2016). Austria, Ireland and the United States used to have entirely separate schemes; now they are fully integrated for the mandatory components applicable to private-sector workers, but civil servants have an additional occupational scheme. Finally, in the last category, only four countries including France, along with Belgium, Germany and Korea, still have totally different schemes covering private- and public-sector workers.

19. The analysis below compares pension entitlements between public- and private-sector full-career average-wage workers. Hence, this case assumes the same work history throughout the career across both sectors, which isolates the impact of differences 
in pension rules. In France, recent measures have led to a closer alignment of rules governing private-sector and public-sector pensions. ${ }^{5}$ Yet, some important differences remain. In short, the public sector provides more generous entitlements from the base salary, but less generous entitlements from bonuses. ${ }^{6}$

20. Figure 3 shows the level of gross replacement rates in the public and private sector for the case mentioned above and for workers now entering the labour market at age 20. These theoretical values are computed based on the OECD pension model from the mandatory pension components as data for voluntary civil-service pensions are not readily available. The retirement age to get a full pension is the same across both sectors in all countries but France. Indeed, as highlighted above, the last private-sector occupational pension reform implies that 44 years will be needed to get a full pension in the private sector while 43 years remain sufficient in the public sector. For comparison purposes, Figure 3 is based on a future effective retirement age of 63 years (age $20+43$ years) for France in both sectors.

21. Consistent with Table 1, pension levels are the same in the public and private sector in about two-thirds of OECD countries. The biggest differences are actually found in countries which have the same base pension but where civil servants benefit from a top-up (third column in Table 1). That top-up is especially large in the United Kingdom, the United States and Canada. By contrast it is relatively small in Australia and Austria. Among the four countries with totally different schemes, Belgium and Germany display the largest replacement-rate difference of about 30 percentage points against 20 p.p. in Korea. This compares to a difference of only 6 p.p. in France, which implies an 11\% lower pension in the private sector relative to the public sector for this case study. About one-quarter of this difference comes from the temporary penalty (section 1.1) that applies to the occupational component of the private-sector pension. ${ }^{7}$

5. This has also been the case in Belgium.

6. Bonuses in the public sector are partly covered by a points scheme. One main assumption in the simulations for France herein relates therefore to the size of bonuses which are considered to be equal to $20 \%$ of the base salary. Based on the latest updated data, this share is equal to $22.5 \%$ (DGAFP, 2018).

7. Based on the OECD pension model, the gross replacement rate at age 63 in the private sector after a full career from age 20 at the average wage is $56.6 \%$. Without the temporary penalty in the occupational pension it would be $58.1 \%$. This compares to $62.6 \%$ in the public sector assuming that bonuses represent $20 \%$ of the base salary. If working one extra year until age 64 to retire with a full pension, the replacement rate in the private sector is equal to $60.5 \%$ (OECD, 2017). 
Figure 3. Differences in gross replacement rates between the public and private sector

Full-career case at the average wage from age 20 in 2016, in percentage points

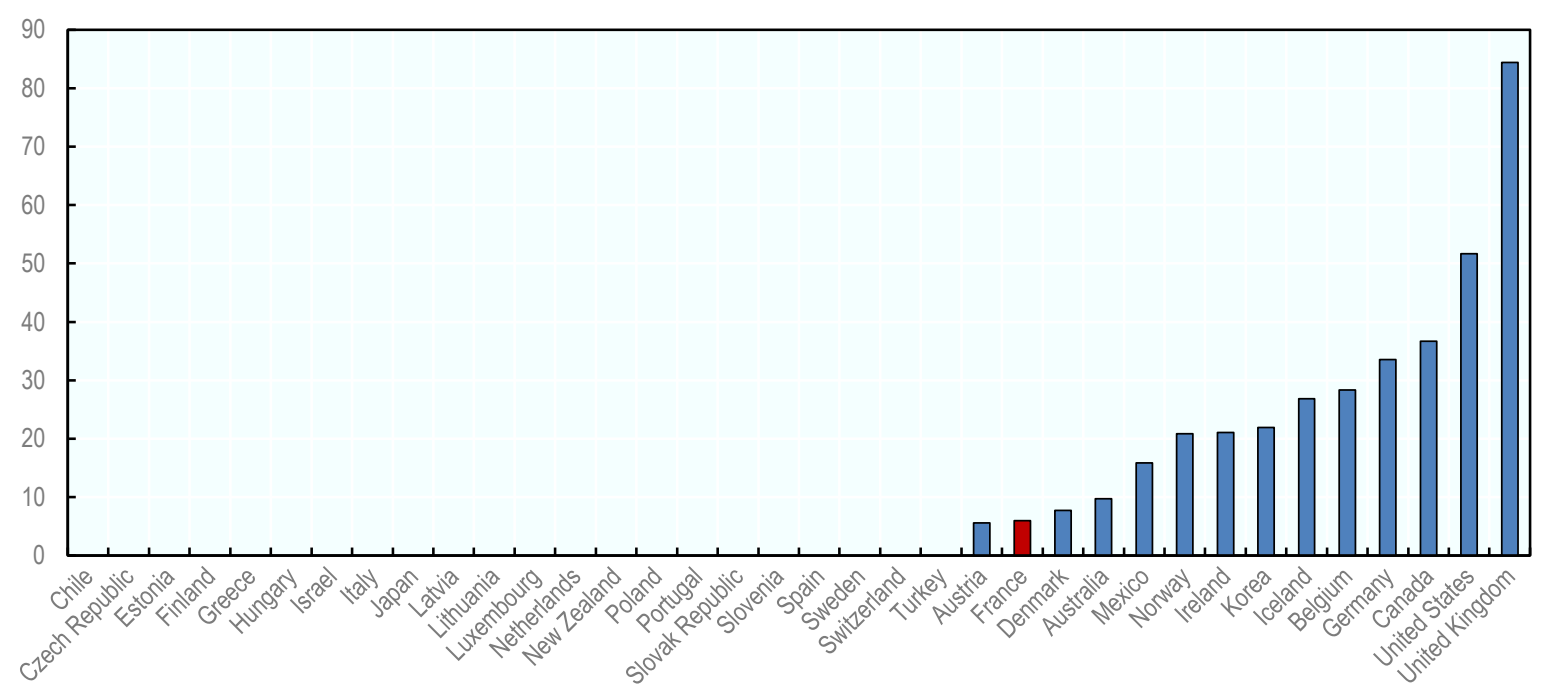

Source: OECD pension model, update of Figure 6.2 in OECD (2016).

22. The heterogeneity of rules in France extends within the public sector, and the simple comparison with the private sector based on the case of civil servants within the central administration is therefore not representative of the whole public sector. Indeed, COR (2018a) highlights that there are wide differences within the public sector, depending in particular on the importance of bonuses in total compensation and on rules for specific professions such as those applying to police officers. In aggregate, to balance civil-service schemes the employer contribution rate paid by the government increased from the already high level of $49 \%$ in the late 1990 s to $74 \%$ since 2014 (126\% for the military scheme since 2014). Those rates, which are influenced by changes in demographic structures, are much higher than those for private-sector workers, even when they are adjusted to account for their application to only the base salary of civil servants; they reflect a large public subsidy. 


\section{How have other countries managed the transition}

23. Publicly provided, earnings-related pension schemes are typically PAYGO and follow three broad types: defined benefit (DB), points, and notional (non-financial) defined contribution (NDC). The 42 mandatory public pension schemes in France mix DB based on different rules and points schemes. With the planned reform, France made the clear choice to keep the core of the pension system as public PAYGO. The new system would include both a unification of all these schemes and the choice of a points system for the unified framework. Section 3 highlights how points schemes relate to DB and NDC schemes.

24. The experience of other OECD countries is useful for the way they managed the transition from a DB system. The impetus for these systemic reforms came mostly from the need to make pensions financially sustainable given ageing prospects. These countries already had a fairly integrated system, except Italy which unified the system with the introduction of the NDC pension and Germany which did not tackle that aspect. This section provides a brief overview of the key issues OECD countries - all in Europe - have been facing in the transition process.

25. Table 2 provides a snapshot of what is covered in this section. Nine OECD countries have introduced a points or NDC system at the core of their public pensions since the early 1990s. Germany is a special case because the system basically worked like a points based scheme before the reform, and because the points scheme only applies to the private sector. The reform was very fast in the Baltic countries and in the Slovak Republic. Better elements of comparison for France are given by Norway and Sweden, with the reform stating to be implemented about 5 years after being legislated and a transition of 10 to15 years. Poland is a similar case. By contrast, Italy has been going through a very long process as no DB entitlement accrued before 2012 were converted into NDC accounts, implying that a person who had just accumulated DB rights at the time of the reform will still be covered by the old scheme for these rights as part of a mixed system.

Table 2. Systemic reforms implementing points or NDC pensions in OECD countries

\begin{tabular}{lcccc}
\hline \multicolumn{1}{c}{ Country } & Type & Legislated (year) & Introduced (year) & Fully applied to new pensions (year) \\
\hline Estonia & points & $1997-1998$ & 1999 & 1999 \\
Germany & points & 1989 & 1992 & 1992 \\
Italy & NDC & 1995 and 2011 & 1996 & $2012-2045$ \\
Latvia & NDC & 1995 & 1996 & 1996 \\
Lithuania & points & $2016-2017$ & 2018 & 2018 \\
Norway & NDC & 2009 & 2011 & $2016-2026$ \\
Poland & NDC & $1996-1998$ & 1999 & $2009 / 2014$ (women/men) \\
Slovak Republic & points & 2003 & 2004 & 2006 \\
Sweden & NDC & 1998 & 1999 & $2003-2018$ \\
\hline
\end{tabular}

Source: Author's contribution. 


\subsection{Germany: Introduction of points in the private sector was just a formal shift}

26. The central element of the German retirement system for private-sector workers is a PAYGO public pension scheme. ${ }^{8}$ Since 1992, benefits have been calculated based on a system of points. Before the introduction of the points scheme, there was already a very close link between contributions and benefits based on a time-constant accrual rate of $1.5 \%$ applying to wages throughout the whole career. The transformation of such a generic DB into a points scheme was therefore straightforward as there is basically an equivalence between the two as shown in section 3. Moreover, this formal "transition" was facilitated because it did not tackle the fragmentation of the system; for example as discussed in section 1 , Germany remains one of the few OECD countries having a totally separated pension scheme for civil servants.

27. Individual pension benefits in Germany depend on the number of points accumulated throughout the career and the point value. The number of points a worker gets every year is equal to its relative earnings such that an average-wage worker earns one point each year. The evolution of the point value, which affects all pensions paid, follows an indexation formula (Box 1 in Section 4). This formula has changed several times over the last decades.

28. Pensions used to be indexed to gross wages although several discretionary deviations since 1957 had led to a 17\% lower pension level in 1992 than what would have resulted based on wage growth (Steffen, 2002). In 1992, indexation was changed as balancing the social insurance budget was expected given population ageing to require extremely high, politically unacceptable contribution rates (Schmäl, 1993). From 1992 onwards, pensions have been indexed to net wages, avoiding that an increase in contribution rates raises the index level. This was actually the main component of the 1992 reform while the formal move to a point unit of account was largely secondary. In 1998, a demographic factor was adopted, revoked in 1999 and finally replaced by a sustainability factor in 2004. The sustainability factor is part of the pension value indexation formula, i.e. it affects how the point value evolves over time (Box 1). The factor tracks the effective dependency ratio, i.e. the relative number of pensioners in and contributors to the scheme, thereby taking account of demographic and labour market developments.

29. In addition to changes within the public pension scheme, there have been major efforts in Germany to move from a retirement system that relies primarily on PAYGO public pensions towards a more diversified system. In 2001, a pension reform ("Riesterreform") introduced financial incentives to invest in individual funded pension products. More recently, private, mostly funded occupational pensions, covering about half of workers, were reformed - they can now be set up as defined contribution plans - with the goal of increasing the number of workers covered by workplace pensions. Nevertheless, the public scheme remains the most important part of the German pension system.

8. After completing the equalisation of pension rules for employees and workers in 1992, the pension schemes covering employees and workers were administratively merged in 2005. 


\subsection{Sweden: Where NDC started at the core of the public pension system}

30. Sweden totally changed its national pension system in the $1990 \mathrm{~s}$, but the starting conditions and the objectives of the reform were different from the current situation in France. The main driver of the need for a big reform in Sweden was the financial unsustainability of the previous system, even though the relatively large buffer funds that had been built helped ensure the financial stability of pensions at the time. In the early 1990s, Sweden faced an acute economic crisis, which compounded public finance difficulties. Beyond financial sustainability issues, other weaknesses in the design of the old pension system gave support to the view that reforming it would be better achieved by changing the whole system rather than by trying to fix its parameters. In France there are good reasons to also call for a change in the system, but the impetus comes from the need for serious improvements rather than from crisis management.

31. Among the weaknesses identified in the old Swedish system were the loose links between pension contributions and benefits. The benefits were based on the best 15 years of earnings with a full pension obtained after 30 years of service. This was regressive, because it was detrimental to workers with a flat career, and was limiting incentives to contribute and therefore to participate in the labour market (Könberg et al., 2006). Also, pension entitlements and pension benefits were indexed to price inflation, which as in France today made the finances of the system overly sensitive to productivity growth in the long term given that revenues follow wage growth. Moreover, there were no rules to deal with the impact of longevity gains and with shifts in the age structure of the population. However, contrary to the current system in France, mandatory pensions were not as fragmented in Sweden and unifying pension rules across schemes was therefore not a factor in the reform process.

32. The timing of the reform was the following. A final report by the Parliament Pension Commission was published in 1990 highlighting the problems of the pension system. The Parliamentary Working Group on Pensions published the essential elements of the reform during the Summer of 1992. The reform legislation was passed by a large majority (85\%) in June 1994, setting out the main components of the future system. That part of the reform was fast, building on thorough assessments of the old system since the 1980s (Settergren, 2003). One component that was not agreed at the time was the balance mechanism, which was legislated in 2001. A PAYGO system be it a well-designed NDC scheme does not automatically achieve financial balance in the short term - nor in the long term as actual longevity typically differs from projected life expectancy when the level of annuities is computed - and requires balancing rules (Section 4).

33. The founding principles of the proposals included a one-to-one relationship between contributions and entitlements, financing based on a stable contribution rate, a substantial reduction in the sensitivity of pension finances to productivity growth, and financial sustainability given ageing prospects hence the need to introduce links to changes in life expectancy in particular. There was no agreement though about whether the system should be PAYGO or funded, but the transition towards a fully funded scheme was ruled out because of its cost (Könberg et al., 2006). As a result of the reform, contributions for the mandatory pensions in Sweden of 17.21 percentage points (p.p.) go to NDC for 14.88 p.p. and to FDC for 2.33 p.p.. While the national system provided a unified scheme for all workers, there were four occupational schemes - blue-collar private-sector workers, whitecollar private-sector workers, municipal employees and state employees - while the one covering central-government employees was transformed into FDC in 2015 with similar contribution rates as for private-sector workers. 
34. Yet the reform process was relatively long with most of the legislation on the new system passed in 1998. The process proved more demanding, both politically and technically, than had been foreseen. Implementation of the principles that parliament decided upon in 1994 took time for several reasons. One party to the agreement needed additional time to discuss the reform (Könberg et al., 2006) and all proposed legislation was scrutinised and agreed on, often after lengthy and difficult negotiations (Settergren, 2003). That period between the 1994 vote and the 1998 legislation was the most critical although $85 \%$ of MPs consistently supported the proposals. Settergren (2003) suggests that the opposition to the reform was close to succeed in stopping the reform but that "only determination, some skilful manoeuvring, the strong loyalty within the Pension Reform/Implementation Group, and an element of luck saved the process".

35. The new pension system went into effect in 1999, with a transition rule of 15 years between generations born in 1938 and 1953. Those born in 1937 or earlier were not affected while for the 1938 cohort, 16/20 of the pension was computed from the old system and $4 / 20$ from the new. Each successive birth cohort was subject to an increase of 1/20 in the weight granted to the new system. Those born in 1954, who were therefore aged 45 at the time, were the first generation whose whole pension was computed based on NDC rules. For those born from 1938, for the part corresponding to the new system, past contributions have been converted into a notional capital. Likewise, for the part corresponding to the old system pension entitlements have continued to be computed based on the old rules up to the 1953 cohort. Assuming a retirement age of 65 , this means that the system went basically through a smooth transition between 2003 and 2018 .

36. Overall the implementation of the new system was a big political achievement replacing a financially unsustainable system by a PAYGO scheme with close links between contributions and entitlements and which takes into account economic and demographic trends to ensure financial sustainability.

\subsection{Norway: Building on the Swedish model with flexible financial management}

37. The Norwegian systemic pension reform drew heavily on changes that took place in Sweden and led to the introduction of an NDC scheme. The main motivation behind the reform was the willingness to reign in projected increases in pension spending given the desire not to extensively tap into oil revenues to deal with the consequence of ageing. The main aspects of the reform were the accounting of earnings throughout the whole career, the links between pension benefits and life expectancy, flexible retirement based on actuarial adjustments between the age of 62 and 75, and less favourable indexation of pensions.

38. The reform process took some time. Two settlements in parliament were reached in 2005 and 2007 with a large majority. They supported a pension reform along the lines of the 2004 report from the Pension Commission which included representatives from political parties (Christensen et al., 2012). The new legislation was voted in 2009. A life expectancy adjustment was introduced for cohorts born in 1944 or later. In addition, the reform was gradually implemented from 2011, with cohorts born in 1953 or earlier being unaffected while those born in 1963 or later will have their future pensions fully calculated based on the new rules. This implies a transition of 10 years. Overall, the reform is estimated to reduce projected pension spending by $3.4 \%$ of GDP in 2060 (relative to a no reform scenario), mostly due to the link between benefits and remaining life expectancy and to indexation rules (Fredriksen et al., 2019). 
39. Beyond some parametric discrepancies between the system in Norway and Sweden, there is one main difference in the principles. There is no balancing mechanism in Norway. This implies that the NDC scheme is simply included as a part of general government finances without a strict accounting separation. Indeed, while the reform created individual pension accounts, they are just used as a way to calculate the pensions. In short, the government budget remains the shock absorber as there is no mechanism linking the final balance with changes in the demographic and macroeconomic environment (Christensen et al., 2012).

40. On top of the national NDC scheme, mandatory occupational pensions exhibit significant differences between private- (mostly DC) and public-sector (DB) workers. The majority of private-sector workers were not covered before 2000 (Kudrna, 2017). In the baseline full-career case discussed in the previous section, civil servants have a DB occupational pension which results in a total benefit which is $46 \%$ higher than for privatesector workers. Along with the 2011 reform, the minimum retirement age for private occupational pensions has been harmonised at 62 . However, there remain important differences in occupational schemes (AFPs) covering public-sector and private-sector workers, which have been until recently early-retirement schemes. AFPs were reformed for private-sector workers in 2011, and now act only as a pension component computed according to NDC principles. In March 2018, trade unions in the public sector and the government agreed to align more closely the public-sector AFPs to private-sector rules.

\subsection{CEECs: Fast transitions amid the transformation of the economies}

41. In the early 1990s, pension systems in Central and Eastern European countries (CEECs) were generally DB and very inequitable with different accrual rates and eligibility conditions across sectors and occupations. Moreover, low effective retirement ages posed serious threat to financial stability, especially given ageing prospects.

42. Unifying fragmented schemes was an important objective of pension reforms in CEECs and the NDC or points framework was often chosen to fulfil that goal. Latvia and Poland introduced an NDC system while Estonia, the Slovak Republic and Lithuania opted for a points system. By contrast, the Czech Republic and Hungary introduced only parametric reforms to their DB schemes. The shift from a DB to an NDC or a points system raised little controversy. The introduction of funded schemes within the reform packages was perceived as a more important systemic change. Indeed, many CEECs added a funded component, following the three-pillar model advocated by the World Bank (1994).

43. In Latvia, the NDC legislation was introduced in 1995 under strong fiscal pressure following the collapse of the Soviet Union. Both the reform process and the transition were extremely fast, and all pensions were granted according to the NDC rules since 1996. The NDC framework was largely influenced by the Swedish design, which had been first presented to the Latvian government in 1994. This implies that automatic links between life expectancy and benefit levels were introduced at the root of the system. Entitlements accumulated prior to 1996 were converted based on NDC rules; they might thus have differed importantly from those obtained from the previous DB scheme. Moreover, the mandatory funded scheme was part of the initial design. Very few public-sector professions remained outside the NDC scheme, but the list of the exemptions has increased in the following years under lobbying pressure, although they still represent a small part of total employment (OECD, 2018a). 
44. Poland introduced an NDC scheme in 1999 after two years of legislative preparations. There was then a broad political consensus such that the change in the government following the 1997 election did not derail the reform momentum. This consensus followed numerous parametric reforms that took place between 1991 and 1995, but were strongly criticised by the Constitutional Court in 1995 (ruling: K 23/95) as undermining the trust in the state and law. Providing special entitlements in terms of early retirement options and higher benefits to some occupational groups, including farmers, miners and teachers, raised political support for the reform. Most of these early-retirement exemptions for selected occupations were removed in 2008.

45. Everyone born after 1949 (therefore younger than 50 at the time), except for some professions, mainly in the public sector, was moved into the NDC scheme while older cohorts remained in the old DB scheme (Chłoń-Domińczak et al., 2013). ${ }^{9}$ Entitlements accumulated before 1999 were converted into some initial notional capital calculated according to the DB pension formula and assuming that the benefits would be paid for the average remaining life expectancy at age 62 in 1999. Women started to retire under the NDC rules around 2009 and men around 2014. As in Latvia, part of the contributions were used to finance the introduction of a mandatory private funded DC scheme within the reform package. This component was subject for the most part to a reversal in 2011 and 2013 as debt-financing transition costs ended up being politically unsustainable.

46. Estonia introduced a points scheme in 1998 to simplify the system and be better prepared to cope with the fiscal pressure due to population ageing. Previously, pensions were based only on the contribution period, implying that there was no earnings-related component. The newly introduced PAYGO scheme consisted of three elements: a basic pension component, a component only based on the length of the contribution period and an earnings-related component based on points. Demographic changes are accounted for through the indexation of the point value. Indexing is not to wage growth but to price inflation plus $80 \%$ of the real growth rate of the contribution base (50\% before 2008$)$, itself influenced by changes in employment. ${ }^{10}$ Pensions started to be paid based on the point formula from 1999, covering the whole population. A funded scheme was added in 2002 and made mandatory for those born in 1983 or later (Raudla and Staehr, 2003).

47. The Slovak Republic transformed its DB scheme into a points system in 2003, with a fast transition: all pensions were paid based on points since 2006. This was a fairly radical because the DB scheme was based on average income from the best 5 out of the last 10 years (Lesay, 2006) while the points system is based on lifelong earnings. The value of the point is linked to changes in the average wage. Among countries with points schemes, the Slovak Republic is specific in that entitlements are converted in euros at retirement (rather than being maintained in points) and pensions in payment are indexed to a different index equal to price inflation plus half real average-wage growth. There is therefore no direct influence of longevity gains or of shifts in the demographic structure on benefit levels. However, the retirement age has been linked to life expectancy, and is projected to increase from 62 in 2016 to 68 in 2060 (OECD, 2017).

48. In 2018, Lithuania moved from DB based on the best 25 years of earnings to the point formula, in order to improve transparency and financial sustainability. The value of

9. Farmers retained a separate scheme, miners were permanently excluded from the NDC system in 2005 as well as teachers born before 1969.

10. Basic pensions in payments are also indexed in the same way. 
the point is linked to the total payroll in the economy, accounting for changes in the size of working-age population. Its initial value was chosen such that the impact on current replacement rates was minimised (OECD, 2018b). Transparency was also enhanced by separating the finances of earnings-related pensions and basic pensions which are increasingly financed by general taxation.

\subsection{Italy: Long transition as past entitlements were not converted}

49. In Italy, pension reforms intensified in 1992 in order to improve financial sustainability given high government debt levels and the need to prepare for the Economic and Monetary Union. The main focus was to raise effective retirement ages as the space to enhance pension finances through increasing revenues was limited (OECD, 1999). The fragmented pension system consisted of PAYGO-DB schemes managed by the National Institute for Social Security. The eligibility and benefit-calculation rules differed substantially between the public sector, the private sector, occupational groups as well as the self-employed.

50. Before the introduction of NDC pensions, some measures had partially reduced differences across schemes. Before 1992, the statutory retirement age was 55 for women and 60 for men in the private sector, and 65 for both in the public sector. ${ }^{11}$ Alternatively, eligibility to pensions, irrespective of age, was possible after having contributed for 35 years in the private sector and 20 and 25 years for women and men, respectively, in the public sector (so-called seniority pensions). ${ }^{12}$ In 1992, the statutory retirement age in the private sector started to gradually increase to 60 for women and 65 for men in 2001. The eligibility conditions to seniority pensions in the public sector started to converge to the private-sector levels. Moreover, the reference wage period to calculate the benefits increased from the last 5 to the last 10 years for current workers and to the whole working life for those starting to work in 1992 or later. Also in 1992, the indexation of benefits shifted from wages to prices. These measures improved pension finances but did not solve financial sustainability issues in the long run (Franco and Sartor, 2006).

51. The NDC system was introduced in 1995 and started to be implemented in 1996. It covered both public and private sectors in the same way. The level of pensions was linked to remaining life expectancy upon retirement through the NDC formula. The new rules provided roughly actuarially neutral penalties for early retirement which was possible from age 57. The minimum pension was abolished for those retiring under NDC rules, retirees with low earnings history being simply covered by the old-age safety net (ChłonDomińczak et al., 2013). The 1995 reform also tightened access to seniority pensions to 35 years with a minimum retirement age of 57 years or 40 years without an age limit. Moreover, the self-employed were initially given preferential treatment in the NDC scheme. ${ }^{13}$

11. Substantial exceptions existed in the public sector, for example blue-collar female workers and local-government workers could retire at 60 .

12. Higher retirement age in the public sector was thus counterbalanced by easier access to the seniority pensions.

13. First, they paid a lower contribution rate of $15 \%$ compared to the $33 \%$ paid by the employees. Second, the contribution rate used to calculate their entitlements was higher at $20 \%$. This initial discrepancy between the contributions actually paid and those generating entitlements was gradually 
52. In Italy, the transition to a full NDC system is very long and complex. First, those with more than 18 years of contribution in 1996 remained (initially, see below) fully outside NDC. ${ }^{14}$ Second, those with less than 18 years of work experience in 1996 started to acquire new pension entitlements based on NDC rules while their previous DB entitlements were maintained and kept independent. This means that past entitlements were not converted into notional accounts contrary to what Latvia and Poland had done. Hence, workers with entitlements from both systems followed mixed rules; in particular their benefits were not fully affected by NDC adjustments for retiring before or after the statutory retirement age. Third, only those who started to contribute from 1996 will have their pensions fully computed according to NDC rules. Consequently, according to the provision of the 1995 reform, the NDC regime would have slowly affected pension expenditure from around 2020 while the old system will only be closed just around the middle of the century.

53. Given intense pressure, the legislation process was very fast, which resulted in serious weaknesses. In particular, the annuity factors used to convert notional accounts into pension benefits were related to age groups rather than both birth cohorts and age groups. They were to be adjusted, in a discretionary way, to life expectancy every 10 years, but in the end no adjustment took place (Schoyen and Stamati, 2013). Later reforms have corrected these flaws.

54. Under strong fiscal pressure exacerbated by the global financial crisis, the 2011 Monti-Fornero reform sped up the beginning of the transition to NDC. From 2012 all new entitlements even for those with long work experience before 1996 were accrued following NDC rules - this was already the case for people with less than 18 years of contributions in 1996. As a result, the NDC benefit calculation started to have an impact in 2012 instead of around 2020 (Chłoń-Domińczak et al., 2013). More importantly, the early-retirement option to retire with 35 years of contribution which had increased from age 57 to 60 was abolished. Early retirement without any age conditions became available only after a career length of 42 years for men and 41 years for a women compared to 40 years before. Moreover, the statutory retirement age increased by one year to 66 for men and started to gradually increase for women to reach 66 in 2018, ensuring convergence of eligibility rules across the public, the private sectors and the self-employed. These changes were unexpected and harsh in some cases: for some workers close to retirement age the eligibility conditions increased by even five years almost overnight (Boeri et al., 2016).

55. On top of that, the statutory and early retirement ages have been automatically linked to changes in life expectancy. Italy is therefore among the few countries with Denmark and Finland, and the only one among those with an NDC system, to link both the benefit level and the retirement age to changes in life expectancy. While, given NDC rules the decision about when to retire is neutral for public finance over time, early retirement can create short-term costs for the public purse offset by medium-term savings.

56. Given the lack of broad support for the 2011 reform, some measures were taken to facilitate early effective retirement. In 2017, subsidised early labour market exit was made possible from age 63 under special conditions (so-called social and financial APE) and, in 2019 , the new government has opened the possibility to retire at age 62 with 38 years of

eliminated in the following years (Marano, 2006 ${ }_{[8]}$ ) and the contribution rate increased to reach $24 \%$ in 2018 .

14. According to Guardiancich et al. (2019), the exclusion of workers roughly older than 40 years was part of the concessions to trade unions, which was crucial for the successful introduction of the NDC design. 
contribution - both measures are temporary, applying until the end of 2019 and 2021, respectively. Still, the NDC formula, and in particular the roughly actuarial reduction in benefits when retiring earlier, remains unaffected.

57. Beyond public finance implications, the statutory retirement age influences social norms about working at older ages and therefore effective retirement ages. If it is fixed while longevity increases, the fear, backed by accumulated evidence (e.g. Bernheim et al., 2001), is that short-sighted behaviours lead to people retiring too early with too low pensions. This is why, even within an NDC scheme, linking the retirement age - at least the minimum retirement age - to changes in life expectancy is useful to improve welfare. It should be noted, however, that the design of the Italian NDC scheme prevents workers from retiring too early with low pensions. First, retiring before the statutory retirement age is possible only if the pension is higher than 2.8 times the amount of old-age social assistance, implying that the gross pension must be higher than $53 \%$ of the average wage in that case (data source: OECD (2017)). Second, retiring at the statutory retirement age requires having an old-age pension benefit of at least 1.5 times the old-age social assistance level ( $29 \%$ of average wage).

\subsection{Belgium: Proposed switch to a points system has been delayed}

58. In 2013, the Belgian government formed a committee of experts to investigate the options for a new pension system. The committee was tasked to enhance "the social and financial sustainability" of the Belgian pension system. In its final report the committee proposed a points system with an automatic adjustment to keep the system financially sustainable for the three pension sub-systems: private-sector workers, self-employed and civil servants. The parameters of the points schemes would differ between the three subsystems, but several proposals include some convergence in terms of full-career length, retirement age and automatic adjustments to various parameters.

59. As for the "standard" points system, the number of points earned for each year of work would be equal to the wage earned in that year divided by the average wage of the economy. Once someone is eligible for retirement the number of points would be added up, multiplied by the point value at the time of retirement and multiplied by an adjustment factor in case someone retires earlier or later than the normal retirement age. According to the proposals, either the normal retirement age or the point value will be adjusted to changes in life expectancy. Moreover, the scheme will include a minimum pension while arduous jobs will receive additional points.

60. Several governments have supported the call for a switch to a points system, but a formal proposal has so far not been presented to Parliament. Given the collapse of the governing coalition in December 2018, a formal proposal is unlikely to be presented before the formation of a new government following the elections in May 2019. The current minority government does not have enough support in Parliament to propose a major pension system overhaul.

\section{To what extent are DB, points and NDC inter-related within PAYGO}

\subsection{Computation of benefits and adjustment rules}


61. Public pensions are typically PAYGO financed. This section looks at the interrelationship between DB, points and NDC within PAYGO schemes. An NDC pension is a DC pension, but in contrast to funded DC the interest rate used to compound contributions is notional, defined as a pension parameter within NDC, rather than being a net rate of return determined by financial returns and fees.

62. Points and NDC schemes refer to entitlements generated by earnings throughout the whole career. Therefore, for comparison purposes, only DB plans based on lifetime earnings are considered here. The analysis builds on the algebra presented in OECD (2005) and Queisser and Whitehouse (2006), and provides new insights by extending the technical framework to changes across generations.

63. This emphasis on the dynamic adjustment of key parameters given the evolution of demographic and economic conditions highlights additional constraints imposed on points and DB rules in order for them to preserve the appealing properties of NDC pensions. Policy makers might be reluctant to implement these additional constraints which limit their flexibility. However, this should be weighed against the benefits brought in terms of robustness, transparency and equity, and in the end of confidence in the system.

64. A generic NDC system is appealing because it is designed to ensure financial stability and avoid that pension finances are sensitive to demographic and economic trends. The counterpart of this financial robustness is twofold. First, cohorts that live longer have, as a rule embedded in the system, to contribute for longer periods to maintain replacement rates at similar levels as older cohorts. Second, for given contribution rates, a generation which relies on a fast growing (declining) working-age population will benefit from higher (lower) replacement rates. This second implication is inherent to PAYGO systems whereby current workers directly finance current pensioners, but it is automatically included in generic NDC schemes.

65. A generic NDC scheme uses the growth rate of the contribution base (closely related to the growth rate of the wage bill) as the notional interest rate while actuarially converting accumulated notional assets at the time of retirement into monthly benefits based on projected life expectancy. In technical terms, the internal rate of return of a PAYGO scheme - which is by definition the return that can be granted, through pension benefits, on pension contributions while ensuring financial equilibrium - is the growth rate of the contribution base (wage bill).

66. The French Pensions Advisory Council (Conseil d'orientation des retraites, COR) notes that differences between DB, points and NDC refer to the technical computation of pension benefits (COR, 2018b). It argues that the main differences refer to the unit of account (unite de compte), but do not change the nature of the system which is better characterised by (automatic) rules to adjust key variables in the system. Hence, according to COR, a more fruitful typology focuses on the management rules of the system.

67. COR (2018b) introduces the concept of defined return (DR). A DR system is defined as granting a defined return equal to the growth rate of the wage bill on contributions paid, while accounting for the life expectancy of each generation to compute benefits at the time of retirement. ${ }^{15}$ The generic NDC is thus DR. In the real word, however, an NDC system can or cannot be generic (Section 4). Likewise, as this section will show, depending on the rules used to compute and index benefits, a DB or a points system can or

15. Any return could a priori qualify as a DR, but schemes using the wage bill growth as the return ensures financial sustainability when accounting for mortality rates to compute annuities. 
cannot be equivalent to a generic NDC and be DR according to COR's methodology. The choice of (constraining or automatic) rules reflecting trends in wages, employment and life expectancy is therefore critical for a good management of the system, be it DB, points or NDC.

\subsection{Points and DB systems}

68. A simple, generic DB plan pays a constant accrual rate, $a$, for each year of service. The pension benefit is:

$$
D B=N a \mathrm{w}_{\mathrm{ref}}
$$

where $N$ is the number of contribution years and $\mathrm{w}_{\text {ref }}$ is the reference wage at the retirement age used for pension purposes. The reference wage depends on how past wages are revalued:

$$
\mathrm{w}_{\text {ref }}=\sum_{i=1}^{N} \mathrm{w}_{\mathrm{i}}\left(1+\mathrm{x}_{\mathrm{i}}\right)^{N-i} / N
$$

where $\mathrm{w}_{\mathrm{i}}$ is individual earnings in year $i$ and $\mathrm{x}_{\mathrm{i}}$ is the average rate at which earnings from year $i$ are uprated. For a given period, this uprating index is common to all workers. In most OECD countries, this is the growth of economy-wide average earnings, but in a few countries including France, past wages in the DB general scheme are uprated in line with price inflation - and only the best 25 years of earnings are accounted for. $N$ is the proxy for the career length and retirement age (minus entry age), with $w_{i}=0$ for periods with no earnings. In the generic case considered here, the pension benefit is then written as:

$$
D B=\sum_{i=1}^{N} \mathrm{w}_{\mathrm{i}}\left(1+\mathrm{x}_{\mathrm{i}}\right)^{N-i} a
$$

Defining $\rho_{i}$ as the growth rate of an individual's wages, the replacement rate at retirement age is therefore equal to:

$$
\mathrm{RR}_{\mathrm{DB}}=\sum_{i=1}^{N}\left(\frac{1+\mathrm{x}_{\mathrm{i}}}{1+\rho_{i}}\right)^{N-i} a
$$

69. Points systems can take different forms with the French Agirc-Arrco scheme being the exception. Technically, the Agirc-Arrco scheme can be seen as more general, implying greater complexity while allowing for more flexibility in the adjustment of parameter values. In this current French points system, pension points are calculated by dividing contributions by the cost of the pension point $(k)$. The pension benefit then depends on the value of a point at the time of retirement, $v$. The cost of a point at a given time is the same for everyone, and likewise for the value. The number of points acquired at each period is equal to $c w_{i} / k_{i}$ where $c$ is the contribution rate. Thus, the pension benefit can be written as:

$$
P P=\sum_{i=1}^{N} \frac{c w_{i} v_{N}}{k_{i}}
$$


70. Key policy variables are the indexation rates of the pension point cost and value, denoted by the parameters $u$ and $n$, respectively, such that $k_{i+1}=k_{i}\left(1+\mathrm{u}_{i}\right)$ and $v_{i+1}=$ $v_{i}\left(1+n_{i}\right)$. By writing the pension point value at the time of retirement as a function of its contemporaneous value, the equation becomes:

$$
P P=\sum_{i=1}^{N} c w_{i}\left(1+u_{i}\right)^{N-i} \frac{v_{N}}{k_{N}}
$$

The replacement rate is then equal to:

$$
\mathrm{RR}_{\mathrm{PP}}=\sum_{i=1}^{N}\left(\frac{1+\mathrm{u}_{\mathrm{i}}}{1+\rho_{i}}\right)^{N-i} \frac{c v_{N}}{k_{N}}
$$

71. By comparing the expressions of pension values for DB and points, it is clear that if the point cost is indexed at the same rate used to uprate past wages in the DB scheme $\left(u_{i}=x_{i}\right)$ then the benefit level is the same between DB and points provided that the value of the point at retirement equals its cost multiplied by the ratio of the accrual rate to the contribution rate: $v_{N}=k_{N} a / c$.

Result 1: There can be a strict equivalence between a points and a generic DB scheme based on lifetime earnings provided that the indexation rate of the cost of points is the same as the uprating rate used for wages in the DB scheme, i.e. if $u=x$.

72. In other countries than France, the cost-of-point concept is not used. The number of points is only determined by the wage relative to the average wage. This has two implications. First, these typical points schemes correspond, in the above general framework, to the case where the cost of points is indexed in line with average-wage growth $\left(u_{i}=\bar{\rho}_{i}\right)$. This means that in these systems, there is equivalence with a DB scheme only if rates used for uprating past wages in the DB scheme is equal to the growth rate of the average wage $\left(x_{i}=\bar{\rho}_{i}\right)$. Second, changing the contribution rate only affects the level of resources, but does not modify entitlements: for a given earnings level, a higher contribution rate does not lead to higher entitlements. That is, in the above framework $k_{i}=$ $c \bar{w}_{i}$, where $\bar{w}_{i}$ is the average wage in period $i$.

73. The Agirc-Arrco points system is actually more opaque because only some contributions generate entitlements. In 2019, about $21 \%$ of paid contributions do not generate entitlements - the so-called taux d'appel is equal to 1.27, i.e. if someone pays 127 euros of contributions only 100 euros are used to purchase points $(1 / 1.27=0.79=1-0.21)$. Increasing this taux d'appel has been used in recent years to raise revenues, something that is achieved in standard points schemes by increasing the contribution rate - which does not generate additional entitlements. Using the taux d'appel is more opaque because the same impacts from increasing the taux d'appel - more revenues but same entitlements - can be achieved simply in the Agirc-Arrco scheme by increasing the contribution rate and lowering the point value.

\subsection{Link with NDC}

74. Notional accounts work like points but the unit value is in euros rather than in the number of points. Inflows are equal to contributions (in euros), i.e. wages multiplied by the 
contribution rate. The notional capital is increased each year by the notional interest rate, $r$. At retirement, the accumulated notional capital is divided by a notional annuity factor, $A_{N}$, sometimes called the G-value, in close relation to actuarial principles (see below). The pension benefit can be written as:

$$
N D C=\sum_{i=1}^{N} \frac{c w_{i}\left(1+r_{i}\right)^{N-i}}{A_{N}}
$$

and the replacement rate is:

$$
R R_{N D C}=\sum_{i=1}^{N}\left(\frac{1+\mathrm{r}_{\mathrm{i}}}{1+\rho_{i}}\right)^{N-i} \frac{c}{A_{N}}
$$

75. The above expressions highlight the equivalence between NDC and points (and generic DB based on lifetime earnings) if the notional interest rate and the indexation rate of the cost of points (and the uprating rate of wages in DB) are identical, i.e. $r=u$ (i.e. $r=x)$ are the same provided that $k_{N} / v_{N}=A_{N}\left(a=c / A_{N}\right)$.

Result 2: There can be a strict equivalence in the static benefit formula between a points and an NDC scheme if the indexation rate of point cost is equal to the notional interest rate, i.e. if $u=r$.

Result 3: There can be a strict equivalence in the static benefit formula from a generic DB scheme based on lifetime earnings and an NDC scheme if past wages in the DB scheme are uprated in line with the notional interest rate, i.e. if $x=r$.

\subsection{Accounting for changes in longevity}

76. One attractive feature of NDC pensions is the link between pension benefits and life expectancy through the annuity factor. Denoting $z$ the indexation rate of pensions in payments, the accumulated notional capital at the time of retirement is actuarially equal to the stream of discounted pension benefits taking into account survival rates $s_{i}$ :

$$
\sum_{i=1}^{N} c w_{i}\left(1+r_{i}\right)^{N-i}=\sum_{i=N+1}^{\propto} \frac{s_{i} N D C\left(1+z_{i}\right)^{i-N-1}}{\left(1+r_{i}\right)^{i-N-1}}
$$

where NDC denotes as above the pension benefit from the NDC scheme at retirement age. It follows that the annuity factor is defined as:

$$
A_{N} \equiv \sum_{i=N+1}^{\infty} \frac{s_{i}\left(1+z_{i}\right)^{i-N-1}}{\left(1+r_{i}\right)^{i-N-1}}
$$

77. When life expectancy increases, i.e. when survival rates rise, the annuity factor increases and the pension benefit from the notional scheme automatically decreases at the same retirement age from one generation to the next. If pension in payments are indexed 
by the notional interest rate, $r$, then the annuity factor simplifies into $A_{N}=\sum_{i=N+1}^{\alpha} s_{i}$ which is equal to the remaining life expectancy at retirement age, denoted $R L E_{N}(t)$. However, it can be decided - without requiring any adjustment in the herein analysis - to boost the initial pension while indexing pensions in payment less generously in order to preserve actuarial principles. For example, if pensions in payment are indexed by $z=r-$ $\beta$ then the annuity factor is lower than remaining life expectancy for any positive $\beta$ :

$$
A_{N}(\beta)=\sum_{i=N+1}^{\alpha} \frac{s_{i}\left(1+r_{i}-\beta\right)^{i-N-1}}{\left(1+r_{i}\right)^{i-N-1}} \approx \sum_{i=N+1}^{\alpha} s_{i}(1-\beta)^{i-N-1}<R L E \text { if } \beta>0
$$

and the initial replacement rate $R_{N D C}(\beta)=\sum_{i=1}^{N}\left(\frac{1+\mathrm{r}_{\mathrm{i}}}{1+\rho_{i}}\right)^{N-i} \frac{c}{A_{N}(\beta)}$ is then larger.

78. The idea is that the choice of a given $\beta$ does not affect total expected pensions but influences the sequence of benefits. A higher $\beta$ (for example price versus wage indexation) implies a higher initial replacement rate as well as a lower replacement rate in a second phase of the retirement period. Given socio-economic inequality in life expectancy, a higher $\beta$ thus tends to benefit more those who are expected to have shorter lives.

79. One key difference between NDC and the other PAYGO schemes is that survival rates do not automatically influence benefit levels in DB or points schemes, and especially not at the individual level depending on the effective age of retirement. Additional rules need to be built into those schemes to maintain the equivalence to NDC pensions when comparing benefit levels across generations given changes in life expectancy.

80. Let $\alpha$ be defined as the annual rate of change of the annuity factor - it can be seen as the growth rate of survival rates or remaining life expectancy. For generations born at time $t$ and $t+1$ this means that $A_{N}(t+1)=A_{N}(t)(1+\alpha)$, and:

$$
R R_{N D C}(t)=\sum_{i=1}^{N}\left(\frac{1+\mathrm{r}_{\mathrm{i}}}{1+\rho_{i}}\right)^{N-i} \frac{c}{A_{N}(t)} \equiv B(r, \rho) \frac{c}{A_{N}(t)}
$$

This follows that from one generation to the next, the NDC replacement rate at the same retirement age decreases at rate $\alpha$.

81. Let's assume that conditions ensuring the equivalence between NDC and points and DB (Results 2 and 3, and therefore Result 1) are met for generation $t$. This means that $x=u=r$, with the following implication. An increase at rate $\alpha$ of life expectancy induces a proportionate fall in the replacement rate at the same retirement age all other things equal. Maintaining the equivalence between DB and points schemes, on the one hand, and NDC, on the other hand, to reflect the automatic adjustment of NDC benefits to changes in life expectancy across generations leads to the following:

- For the DB scheme, keeping the retirement age fixed, accrual rates should fall at the same rate $\alpha$ from one generation to the next: $a(t+1)=a(t) /(1+\alpha)$.

- For points schemes, the rule should ensure that $v_{N}(t+1) / k_{N}(t+1)=$ $v_{N}(t) / k_{N}(t) /(1+\alpha)$, which implies that $(1+n) /(1+u)=1 /(1+\alpha)$. This means that beyond the indexation of the cost of a point at the notional interest rate, the point value should be indexed at the notional interest rate minus the growth rate of life expectancy. 
Result 4: In order to ensure automatic adjustments of pension benefits to life expectancy gains in line with NDC pensions, on top of assuming that the equivalence condition $x=$ $u=r$ for a given generation is met, the value of the point has to be indexed to the notional interest rate minus the growth rate of remaining life expectancy $(n=u-\alpha)$ while the accrual rate of DB schemes has to decline at a pace equal to life expectancy gains.

On average across OECD countries, remaining life expectancy at 65 is projected to grow by $0.47 \%$ per year on average by 2050 and by $0.42 \%$ in France (Section 4 ). ${ }^{16}$

\subsection{Financial sustainability and internal rates of return}

82. Another attractive feature of NDC is that well-chosen notional interest rates ensure financial sustainability. For that, they should equal the internal rate of return of a PAYGO scheme which is equal to the growth rate of the contribution base or the wage bill for a constant contribution rate. This has one crucial implication. As shown above, points systems which do not use the cost-of-point concept implicitly uprate past wages with average wage growth $\left(u_{i}=\bar{\rho}_{i}\right)$ and cannot mimic NDC based on the PAYGO internal rate of return as economic and demographic factors affecting total employment are not accounted for. This is potentially an important source of imbalances, requiring some adjustment mechanism, as discussed in greater detail in Section 4.5.

83. If it is assumed further, simply for illustration purposes, that NDC pensions in payments are indexed with the notional interest rate $(x=r)$ and that in the steady state the size of the labour force is constant, then for stable unemployment rates the wage bill grows at the same pace as wages, i.e. $r=\rho$. In that case, $B(r, \rho)=N$ and the expressions for replacement rates simplify into:

$$
R R_{N D C}(t)=\frac{c N}{R L E_{N}(t)} ; \operatorname{RR}_{\mathrm{DB}}(t)=N a(t) ; \operatorname{RR}_{\mathrm{PP}}(t)=N \frac{c v_{N}(t)}{k_{N}(t)}
$$

84. The NDC expression based on stable demographics captures the key feature that the NDC replacement rate ensuring financial sustainability is equal to the contribution rate multiplied by the ratio of the career length to remaining life expectancy. To maintain the replacement rate constant given changes in life expectancy then the retirement age needs to change so as to ensure that the ratio of the career length to the length of retirement $N / R L E_{N}(t)$ is constant. This increase in the retirement age, in turn, neutralises the decline in the accrual rate within DB scheme and the lower indexation of the point value relative to its cost in points schemes.

85. In short, although DB, points and NDC schemes can appear very different, they can in fact be closely related variants of earnings-related pension schemes (Börsch-Supan, 2004; OECD, 2005; Whitehouse, 2012). However, one key difference highlighted here in Result 4 is how benefits are adjusted to demographic changes across generations, to changes in mortality rates and in the size of the labour force in particular. NDC schemes are attractive because they embed automatic adjustments to a changing environment. This section has highlighted the needed rules DB and points schemes should follow in order to

16. Compared with an NDC scheme, a points system has less flexibility in the sense that pensions in payments also evolve in line with the indexation of the point value. This means that $z=n=r-\alpha \quad$ and therefore the parameter values should be calibrated such that $\frac{k_{N}}{v_{N}}=$ $\sum_{i=N+1}^{\propto} \frac{s_{i}\left(1+r_{i}-\propto_{i}\right)^{i-N-1}}{\left(1+r_{i}\right)^{i-N-1}}$ 
preserve financial sustainability in line with NDC pensions. The choice of these automatic rules are crucial for an effective management of PAYGO schemes.

\section{Key parameters of the new system}

86. In November 2018, the High Commission for Pension Reform provided some key principles of the reform aimed at introducing a universal PAYGO points system following a wide range of consultations with many stakeholders and services within the administration:

- All 42 regimes will be included based on common rules and replaced by the universal points system. More precisely, the same rules including redistribution mechanisms should apply to private- and public-sector workers, the self-employed, liberal professions and farmers.

- Private- and public-sector workers will acquire points from the same contribution rates, around $28 \%$ in total, bonuses will be included for civil servants and workers in special regimes, while the self-employed will "benefit from an adapted contribution regime so as not to disrupt the economic equilibrium of their activity".

- Financial stability and sustainability should be ensured, and in particular the system should be designed such that it is resistant to economic and demographic shocks.

- Pension entitlements will accrue up to a wage ceiling of 3 times the social security (annual) ceiling (PASS).

- The minimum retirement age will be maintained at 62 .

- Points will be allocated for each child and for career breaks (related to unemployment, maternity leave, sickness, disability, etc.); specific situations will be accounted for (long careers, arduous and hazardous work, handicap).

- The system will include a survivor and a minimum pension scheme.

- There will be a gradual transition and those older than 57 years when the reform is adopted will not be affected by the reform.

87. This section discusses the implication of the planned reform in terms of: pensionable earnings; indexation rules; length of the transition period; redistribution; and, the need of further adjustment mechanisms. 


\subsection{Reference wage}

88. Points are acquired throughout the career, so by definition in a points system similar to DC schemes, whether funded or notional, lifetime earnings are accounted for while the notion of a reference wage is not relevant per se. For France, this will represent a big change since the current reference wage for private-sector workers is based on the best 25 years of earnings while for civil servants it is the wage over the last 6 months. Taking into account the full career is both more transparent and equitable. While it is true that taking into account only the best years protects against some forms of career breaks, it also generates perverse, regressive effects by favouring workers experiencing large wage improvements who tend to be high-wage earners, as the low-wage periods (typically at the beginning of the career) are ignored (Aubert and Duc, 2011).

89. The majority of OECD countries take into account wages throughout the whole career. Recently, the Czech Republic, Greece and Norway joined this group. Today, for private-sector workers, only Austria, France, Slovenia, Spain and the United States take into account part of the career only (Figure 4). Based on current legislation, there will be a gradual increase from 21 to 25 years in Spain and from 30 to 40 years for the 1954 cohort in Austria while for the generations born from 1955 lifetime earnings will apply.

\section{Figure 4. Few OECD countries take into account wages for only part of the career}

Number of years used to compute the reference wage

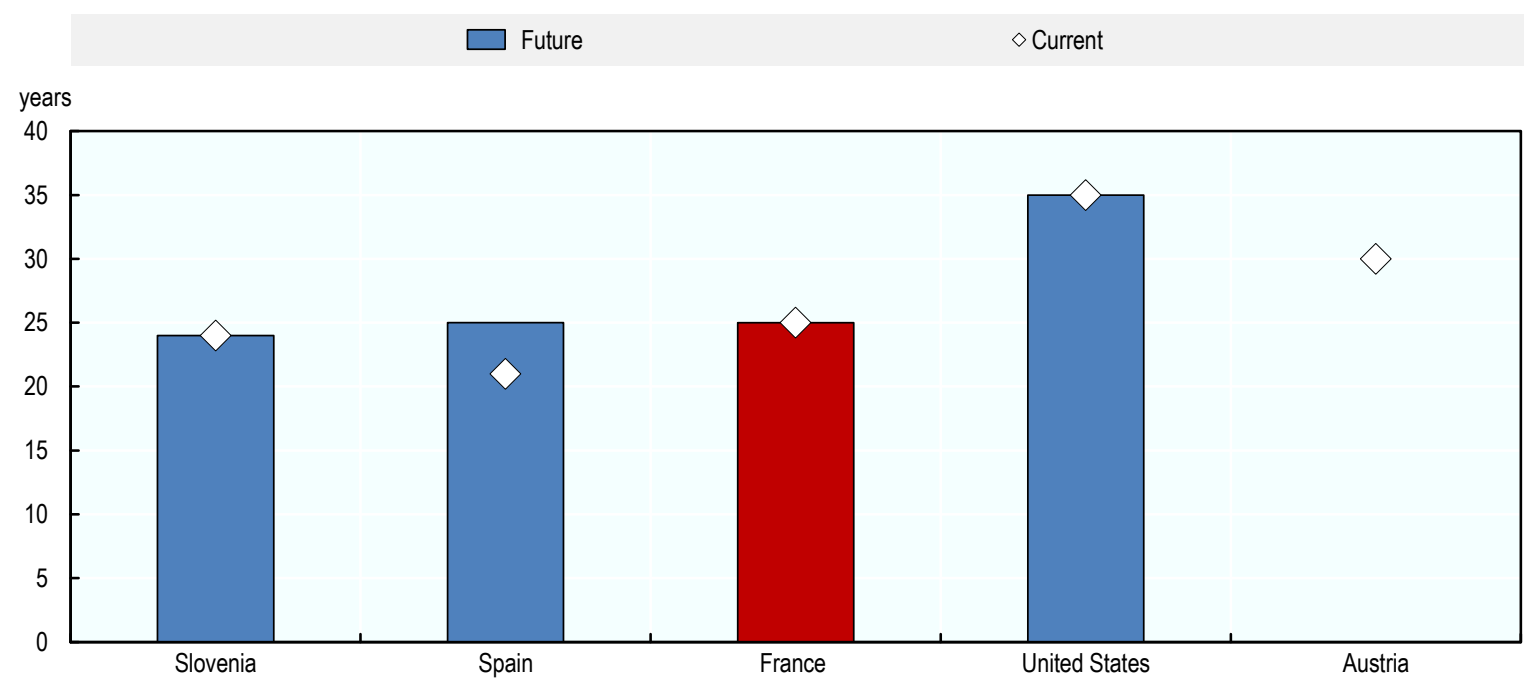

Note: In Austria, the contribution base will steadily increase and reach 40 years for the 1954 birth cohorts while for generations born from 1955 it will be the whole lifetime. In Portugal, 40-year is considered to be the full career, and 45-year in Belgium.

Source: OECD.

90. On top of the contribution period, the wage ceiling for pensionable earnings is another key parameter. It was decided that the unified pension system will take into account earnings up to 3 times the social security threshold (PASS), which means slightly more than 3 times the average wage. At about 3.0 average wage, the proposed ceiling is slightly above the average of 2.6 among countries which have a ceiling (excluding France), however, eight countries have no ceiling at all (Figure 5). With more than 8 times the 
average wage, France is at a record high level. That ceiling is larger than 5 times the average wage in only Mexico and the Slovak Republic.

91. Before the merger of Agirc and Arrco, implemented as of January 2019, the Arrco ceiling was equal to 3 PASS while the Agirc ceiling was 8 PASS. With the merger, the Agirc-Arrco ceiling was set at 8 PASS. The agreed threshold of 3 PASS for the universal points system is therefore much lower, which is welcome as a threshold level of 8 PASS, beyond being very high in international comparison, is regressive as those with high incomes live longer on average and thus tend to benefit from high pensions from a longer than average retirement period (OECD, 2017).

92. This ceiling parameter for pensionable earnings is also important for financing the transition if the same ceiling applies to contributions paid; in that case, a low ceiling reduces current revenues while affecting spending over time only. The choice of 3 PASS might imply that, during the transition, contributions are collected up to 3 PASS while pension rights which have accumulated up to 8 PASS will have to be financed. It could also in theory be decided to have different ceilings for contributions and pensionable earnings. This is the case in Norway which has a ceiling on pensionable earnings while contributions are paid on total earnings. This can make the system very progressive. One normative question - which answer is political - is whether redistribution arising from contributions paid above the entitlement ceiling should instead be financed by general taxation. In any case, such a mechanism would not be consistent with the general principle of the ongoing French reform, according to which the same rights are granted for each euro that is contributed.

Figure 5. Ceiling on pensionable earnings, mandatory pensions

In number of average earnings

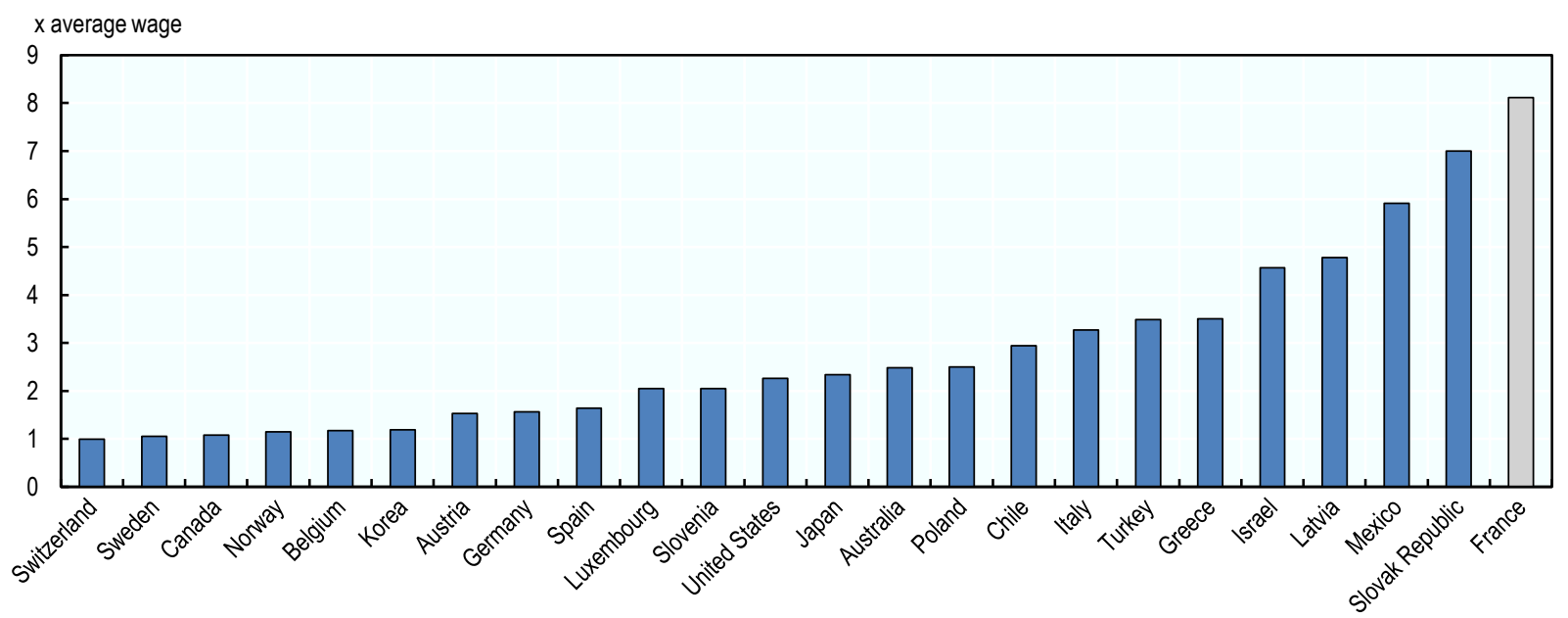

Note: The Czech Republic, Denmark, Estonia, Finland, Hungary, Iceland, the Netherlands and Portugal have no ceiling. In Sweden, the ceiling refers to NDC and FDC pensions, while there is no ceiling for quasi-mandatory occupational pensions which substitute the FDC scheme above its ceiling. There is no relevant number for Ireland, New Zealand and the United Kingdom as there is no mandatory earnings-related scheme.

Source: Indicator 3.6 in OECD (2017) while accounting for 8 PASS for the merged Agirc-Arrco scheme. 


\subsection{Indexation of the cost and the value of points}

One key principle guiding the reform is that the system should be financially stable and sustainable, and resistant to demographic and economic shocks (see above). This imposes some rules to index the cost and the value of points.

\section{Adjustments to wage growth, employment growth and longevity gains}

93. Indexation rules are essential. Section 3 showed that points and NDC pensions can be closely related. The main advantages of well-defined NDC schemes is their robustness to economic and demographic shocks in the long term even though some monitoring and adjustments are still needed (section 4.5). Their main shortcoming lies in the difficulty workers might have to grasp the concept of notional accounts, how they evolve over time and what they concretely imply for the level of benefits (Sundén, 2013). It might be difficult to reach participants with messages of NDC pensions (Holzmann, 2017).

94. Hence, despite the highlighted close relations, points are simpler, and French workers are also more familiar with them as Agirc and Arrco schemes have been operating at a large scale for about a half century. Points might also offer more flexibility as for example the implications of changes in longevity are not fixed in the rules. This flexibility is, however, its main weakness since it means that points schemes are prone to political risks and, more importantly, it implies that financial sustainability is not ensured unless additional indexation rules are developed. Indexation mechanisms should therefore be designed in a transparent way such that the key strengths of NDC schemes are preserved within the points system.

95. The first crucial principle is to eliminate the dependence of both replacement rates and pension finances on real-wage growth. This dependence within the current French system stems from both the price uprating of past wages in the general scheme - formalised by the 1993 reform - the price indexation of the cost and the value of the point, which has often been applied discretionarily in the Agirc-Arrco scheme, and the price indexation of pensions in payments. The main objective of the 1993 reform was to diminish spending. Price uprating was chosen because it was socially and politically more easily accepted given its relative complexity and the related lack of understanding of its implications for pension benefits. It would have been better and more transparent, but then less easy politically, to maintain wage uprating while lowering accrual rates, i.e. in the French general regime lowering the so-called full-rate (taux plein) parameter of 50\%.

96. The reference to price uprating of past wages and price indexation of pensions in payment has three main implications. First, changes in benefits diverge from wage trends, which raises (lowers) initial replacement rates when real-wage growth is lower (higher) than expected. Second, pensions tend to fall relative to wages during the retirement period. Third, this creates a wedge between pension revenues, which come mostly from contributions and thus tend to follow wage trends, and pension spending, making the financial balances highly dependent on real-wage growth, i.e. over time on productivity gains, a parameter that is typically difficult to influence by policy makers. ${ }^{17}$

97. The fact that replacement rates and pension finances become sensitive to productivity growth is thus an undesirable property of the schemes which do not uprate

17. Moreover, uprating past wages mostly with prices essentially gives lower weights to wages earlier in someone's career, creating path dependence. 
past earnings with wage growth, such as in France and Portugal. Avoiding such a dependence was one key element put forward in the design of the NDC scheme in Sweden (Section 2). Eliminating this sensitivity does not imply that the cost and value of the point and the indexation of pensions in payments should equal wage growth, but that they should evolve one to one with wage growth; for example they could be indexed to wage growth minus $\mathrm{x} \% .^{18}$

98. The second crucial principle is to limit as much as possible the impact of employment changes - both long-term trends and cyclical effects - on financial stability. As discussed in section 3, this means that the indexation mechanisms should be based on the internal rate of return of PAYGO schemes and include changes in the number of contributors on top of wage growth. That is, the rules should refer to the contribution base, i.e. the wage bill growth, rather than the wage growth. Using the wage bill growth instead of wage growth allows to account for unexpected changes in employment. To avoid some possible sharp adjustments related to large economic cycles the change in employment parameter can be smoothed over a few years. Auerbach and Lee (2009) shows that an NDC or a generic points scheme based on the wage-bill growth rather than wage growth is inherently more stable financially.

99. Over the last two or three decades, the average annual wage-bill growth has been equal to $1.7 \%$ in France in real terms compared with an average real-wage growth of $1.0 \%$. Figure 6 provides some order of magnitude of what the difference referencing to the wagebill growth instead of the wage growth can make in the future among OECD countries. For illustration purposes, the reported numbers are only based on demographic changes affecting the population aged between 20 and 64 over the next 30 years, thereby ignoring projected changes in employment rates. The range is between a fall of about $1 \%$ per year on average in Central and Eastern and Southern European countries, Japan and Korea to an increase of more than $1 \%$ in Israel.

100. In France the size of the working-age population is projected to be stable over that period, such that indexing based on the wage bill rather than wages would make limited differences. Norway and Sweden use only wage growth as their notional interest rate while the working-age population would increase by $0.5 \%$ and $0.3 \%$ per year on average, respectively. This means that in these two countries the favourable expected demographic developments are not reflected in the return granted to contributions.

101. Total employment does not move one to one with the size of the 20-64 population of course. However, over a very long period - since 1955 - total employment grew by $0.60 \%$ per year on average in France while the 20-64 population grew by $0.61 \%$. Over a more recent period, since 1990 (or 2000), employment rates have been increasing such that total employment grew each year on average by one-quarter of a percent faster than the working-age population ( $0.57 \%$ vs $0.33 \%$ since 1990 , and $0.52 \%$ and $0.26 \%$ since 2000$){ }^{19}$ Assuming this trend is prolonged would imply that total annual employment in France

18. For example, in the OECD pension model, real wages are assumed to grow by $1.25 \%$ per year which implies that for projections with indexing to wage growth $-1.25 \%$ is numerically equivalent to price indexation.

19. Source: OECD Labour Force Statistics and United Nations, Department of Economic and Social Affairs, Population Division (2017). World Population Prospects: The 2017 Revision, DVD Edition. 
would grow by 0.25 percentage point faster than the -0.06 p.p. shown in Figure 6, or 0.19\% per year in total.

Figure 6. Projected change in the working-age population

Projected change in the population aged 20-64 in OECD countries between 2015 and 2045

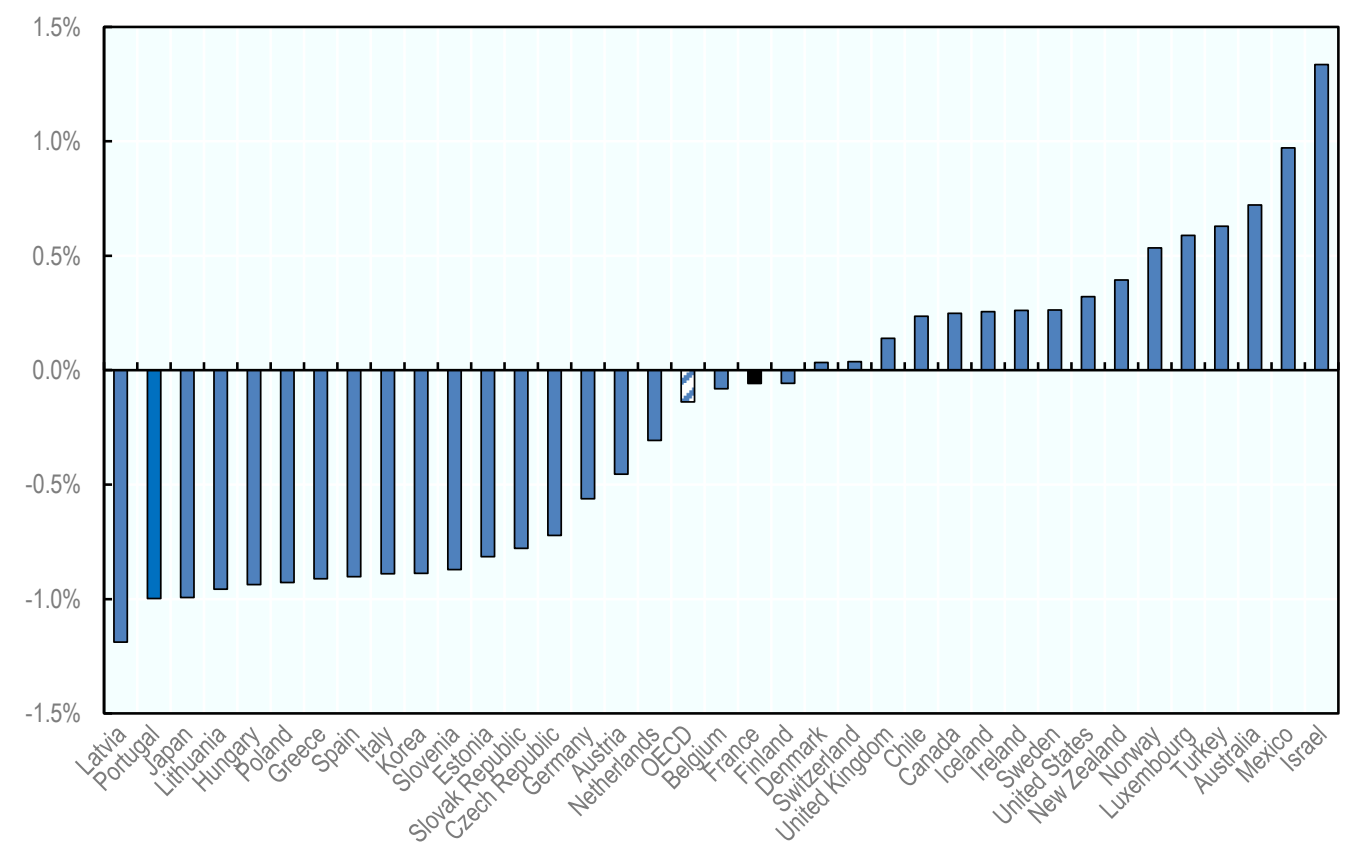

Source: United Nations, World Population Prospects - 2017 Revision.

102. The third key principle is to account for changes in longevity, which are currently reflected in projected improvements in life expectancy. This is important both to ensure financial sustainability and inter-generational equity. Section 3 showed that within points scheme the actuarial adjustment from one cohort to the next implies indexing the point value at a given age by subtracting the growth rate in life expectancy (at a given retirement age) from the indexation rate of the point cost.

103. Figure 7 shows the projected annual change in remaining life expectancy at age 65 across countries for the next three decades. It would be around $0.4 \%-0.5 \%$ on average for most OECD countries including France. Longevity gains will be slowing from $0.7 \%$ over the last three decades in the OECD and from $0.8 \%$ for France. This means that if the growth in the contribution base (or the wage bill) is used for indexing pensions in payment, the point value would be indexed by the annual change in the contribution base minus $0.4 \%$, with this $0.4 \%$ being periodically revised to account for updates in longevity projections. 
Figure 7. Annual increase of life expectancy at 65 between 1980 and 2050

Averaged annual rate, OECD and G20 countries

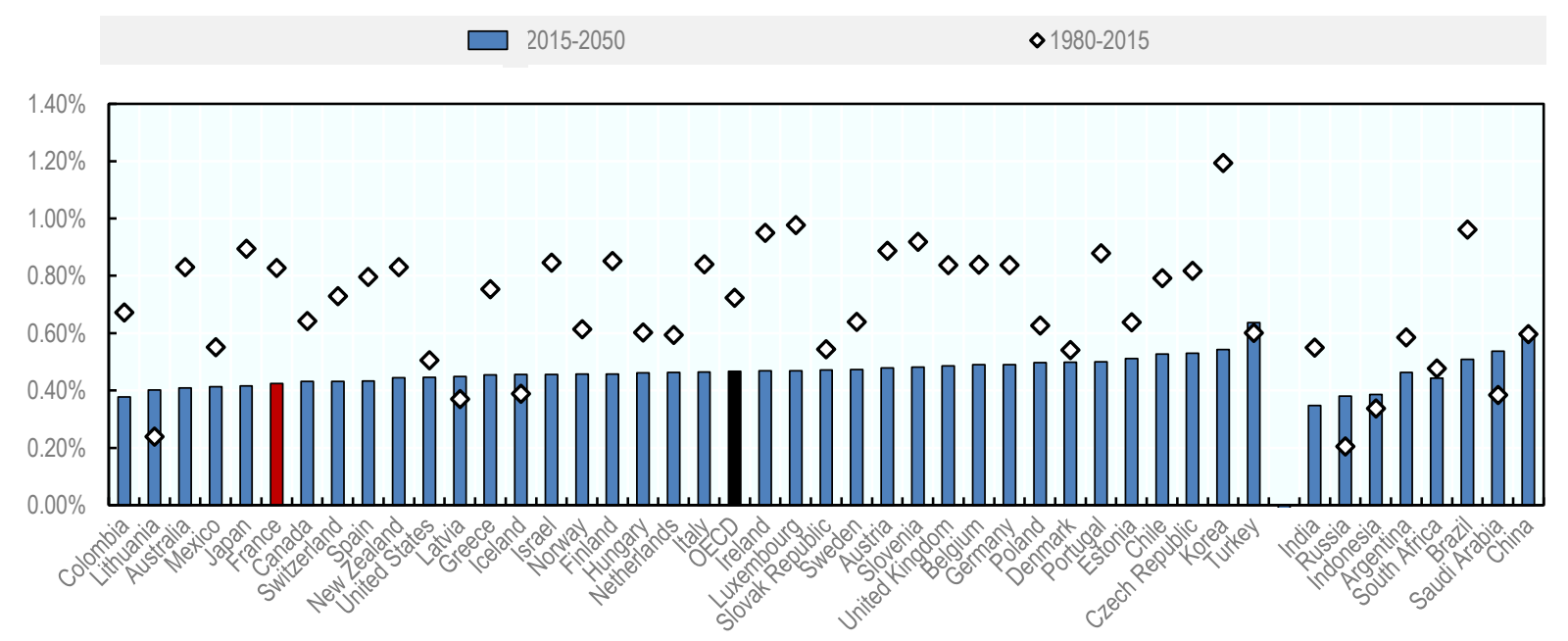

Source: OECD calculation based on the United Nations, Department of Economic and Social Affairs, Population Division, World Population Prospects: The 2017 Revision.

104. To sum up, in the generic points system that limits the building up of large financial imbalances as a result of trends in wages, employment and demographics:

- The cost of the point is indexed to the growth of the contribution base (wage bill).

- The value of a point is defined at the cohort-age level, i.e. it differs for a given cohort depending on the age of retirement and it differs at the same retirement age across cohorts.

- The value of the point at the same age from one cohort to the next is based on the same index while accounting for the growth rate of remaining life expectancy at older ages. Given current longevity projections, this means that the index would subtract $\alpha=0.4 \%$ from the growth of the contribution period. This adjustment should be revised based on updated projections of mortality rates.

- As discussed in section 3, the taux d'appel concept should be eliminated, but one open question is whether the wage ceiling should be higher for contributions than for pension entitlements, depending on the choice made on how to finance redistribution.

- According to current projections of the working-age population, using the growth rate of wages rather than the wage bill might make little difference in France. However, this would expose financial balances to unexpected employment trends.

\section{Comparison with countries having a points or NDC scheme}

105. Table 3 summarises how countries implicitly uprate past wages, index pensions in payments, account for employment trends and changes in longevity within their points or NDC scheme. Uprating past wages are embedded in rules governing points and NDC schemes through the indexation of point cost and the chosen NDC interest rate, respectively (Section 3). The Agirc-Arrco scheme is singular as it is the only one relying on discretionary rules. The differences across countries shown in this table highlight that 
practically the NDC or points labelling is far from being sufficient to characterise a pension system. Accounting for the rules that are put in place is crucial to make the comparison relevant, as discussed in the section 3. On one extreme, rules can be closely related to actuarial principles and sustainable returns, thereby contributing to financial stability but limiting room for manoeuver for policy makers, and for manipulation as well. On another extreme, there can be a total discretion left to the managers, such as in the Agirc-Arrco scheme, which limits transparency and confidence in the system.

Table 3. Rules for pension entitlements, initial benefits and indexation

Points and NDC schemes

\begin{tabular}{|c|c|c|c|c|}
\hline Country & Type & $\begin{array}{l}\text { Uprating of past wages (cost of } \\
\text { points/valorisation of notional accounts) }\end{array}$ & $\begin{array}{l}\text { Initial pension (point value / } \\
\text { life expectancy (LE) link) }\end{array}$ & $\begin{array}{l}\text { Indexation of pensions in } \\
\text { payment (point value) }\end{array}$ \\
\hline (1) & (2) & (3) & (4) & (5) \\
\hline Estonia & points & wages & mix wage bill and prices & same as (4) \\
\hline Germany & points & wages & wages + adjustment factors & same as (4) \\
\hline Italy & NDC & GDP & link with LE & prices \\
\hline Latvia & NDC & wage bill & link with LE & mix wage bill and prices \\
\hline Lithuania & points & wages & wage bill & wage bill \\
\hline Norway & NDC & wages & link with LE & wages $-0.75 \%$ \\
\hline Poland & NDC & mix wage bill and GDP & link with LE & mix wages and prices \\
\hline Slovak Republic & points & wages & wages & mix wages and prices \\
\hline Sweden & NDC & wages + balancing mechanism & link with LE & (3) $-1.6 \%$ \\
\hline Agirc-Arrco & points & discretionary & discretionary & discretionary \\
\hline $\begin{array}{l}\text { generic points } \\
\text { system, France }\end{array}$ & points & wage bill & wage bill - $\alpha$ & $\begin{array}{l}\text { wage bill }-\beta \\
\text { see text }\end{array}$ \\
\hline
\end{tabular}

Source: Author's contribution based on OECD information.

106. In terms of the (implicit) uprating of past wages (column 3), all nine countries refer to wage growth and not to price inflation, if one assumes a stable labour share in GDP. Italy, Latvia and Poland also takes into account the change in employment through the wage bill or GDP, which makes uprating consistent with the internal rate of return of the PAYGO scheme. In the other countries, changes in the size of the labour force are not reflected, which makes the system less stable (Auerbach and Lee, 2009), generating the need for another instrument to adjust benefits and/or finances. Only, Germany and Sweden have implemented adjustment rules, which are discussed in section 4.5.

107. Changes in life expectancy are automatically embedded in the computations of the initial pension (column 4) in NDC countries. Among countries with points schemes, only Germany account for demographic shifts through the sustainability factor, while Estonia, Lithuania and the Slovak Republic do not link benefits to longevity trends. But even in Germany, demography affects the point value in the same way for everyone: there is no direct impact on individual benefits of remaining life expectancy for an individual of a given age and cohort.

108. As shown in Section 3, if well-designed there is flexibility in the choice of indexing pensions in payment. In most countries, indexation of pensions in payments depart from the internal rates of return by ignoring employment trends (column 5). Lithuania is an exception by indexing to wage-bill growth, while Germany and Sweden include, through their adjustment mechanism, some employment-related effects. Moreover, Estonia, Italy, 
Latvia, Poland and the Slovak Republic use price indexation at least partly, which makes their system sensitive to productivity growth. This is avoided in Norway and Sweden, which subtract $0.75 \%$ and $1.6 \%$ to wage growth, respectively. These parameters are supposed to proxy long-term real wage gains, but have no first-order effects as they are also used as the discount rate to compute the initial pension. Similarly, Italy uses a real discount rate (of $1.5 \%$ ), but indexes to price inflation.

\section{Generic points system in France}

109. For the new French system, some specific rules are worth considering (last row in Table 3). First, the anchor of indexation rules should be based on wage growth rather than price inflation to avoid the sensitivity of pension finances to long-term productivity growth. Second, to avoid sensitivity to employment trends and better reflect the internal rate of return of the PAYGO scheme, indexing the cost of points would preferably be based on the growth of the wage bill (or contribution base) instead of the wage growth. For France it might effectively make little difference over time based on Figure 6.

110. Third, longevity trends should be taken into account to index the point value. Given current projections of mortality rates, the indexation of the point value at the same age from one cohort to the next should be equal to the wage-bill growth $-\alpha=0.4 \%$, with this $0.4 \%$ adjustment to be updated based on changes in mortality rates. Fourth, there is flexibility to index pension in payments in an actuarial way; the more generous the indexation the lower the initial replacement rate in line with the discussion in section 3.4 about the impact of the $\beta$ parameter. In practice, making these rules operational implies to convert pension entitlements (number of points * point value) in euros at the time of retirement and index the benefit during the retirement period.

111. Within the pre-reformed system, a French private-sector average-wage worker with a full career from age 20 in 2016 (1996 birth cohort) will retire with a full pension at age 64. This cohort can indeed retire in that case with a full pension in the general regime after 43 years of contribution, i.e. at age 63. However, if retiring at 63, the Agirc-Arrco component will in that case be subject to a temporary penalty of $10 \%$ (see above). Hence, 64 is the future retirement age without penalty after a full-career from age 20. According to OECD (2017), the gross replacement rate at that age is equal to $60.5 \%$, against $52.9 \%$ on average across OECD countries. For illustration purposes only, here are the results of some simulations (Table 4), which are based on the following assumptions:

- Projected UN unisex mortality rates for this cohort consistent with OECD (2017).

- Real wages growing at $1.25 \%$ per year such that price indexation is numerically equivalent to wage indexation minus $1.25 \%$.

- Wage bill growing in real terms in line with Figure $6+0.25 \%$, thus at the average wage rate $-0.06 \%+0.25 \%=$ wage growth rate $+0.19 \%=1.44 \%$.

- $\beta=1.25 \%+0.19 \%=1.44 \%$, i.e. pensions in payment growing in nominal terms at the wage-bill growth rate $r$ minus $\beta$ ensuring stable projected benefits in real terms throughout retirement in France.

- Contribution rate of $28 \%$ mentioned by the High Commission for Pension Reform as a reasonable target for the new system (see above).

- Equivalence with the generic NDC highlighted in Section 3 holds. That is, the cost of points increases in line with wage-bill growth while the point value increases 
for a given age at the wage-bill growth rate minus the growth rate in life expectancy $(\alpha=0.4 \%)$.

112. Based on these assumptions, the replacement rate would be equal to:

$$
R R=\sum_{i=0}^{63-20}(1+0.19 \%)^{44-i} \frac{28 \%}{A_{1996}} \quad \text { with } A_{1996} \equiv \sum_{i=65}^{\propto} \frac{s_{i}\left(1+r_{i}-1.44 \%\right)^{i-N-1}}{\left(1+r_{i}\right)^{i-N-1}}
$$

The average-wage worker of the 1996 cohort would thus retire at age 64 in 2060 with a gross replacement rate of $57.2 \%$. Within this framework, retiring earlier or later automatically affects pension benefits, through both the number of acquired points and the point value which should vary by age and cohort. For example, retiring at age 62 or 68 would lead to a replacement rate of $51.2 \%$ or $70.2 \%$, respectively (Table 4 , Panel A). This implies a bonus (penalty) of about $4 \%$ on pensions per year of deferral (anticipation).

113. Likewise, the replacement rate at a given age automatically adjusts to account for changes in longevity. Assuming that the 1973 birth cohort is the first generation to which the reform fully applies, their replacement rate at age 64 would be $62.8 \%$, declining to $57.2 \%$ for the 1996 cohort and to $52.2 \%$ for those who are born now (2019 birth cohort) (Panel B). This means that at the same age the replacement rate declines by about 1 percentage point compared with the generation born about 4.5 years earlier. Those born in 1996 would have to retire almost two years later ( 22 months) than those born in 1973 to maintain the same replacement rate.

114. Indexation of pensions in payments can be chosen with some flexibility while preserving actuarial principles based on both accumulated pension rights and expected longevity. The replacement rate of $57.2 \%$ at age 64 for the 1996 cohort is obtained when indexing pensions in payment to the wage-bill growth minus $1.44 \%$, which is numerically equivalent in the simulation to price indexation, thereby stabilising the purchasing power of pensions during retirement. With such an indexation, the replacement rate would tend to fall, reaching $41.5 \%$ at age 90 . Instead, indexing pensions more generously at the wage-bill minus $0.19 \%$, which is equivalent in the simulation to wage indexation, would maintain the replacement rate constant throughout retirement, albeit at a lower initial level of $48.1 \%$ (Panel C). ${ }^{20}$

115. In this setting, replacement rates are directly linked to the contribution rate. If all redistribution mechanisms are financed by taxes, the typical case studied above generates a replacement rate of $57.2 \%$ based on a contribution rate of $28 \%$. If out of this $28 \%$ contribution rate 3 percentage points are used to finance redistribution, then the cost or the value of the point should be adjusted proportionally and the replacement rate of the fullcareer case is lower (assuming the typical case studied here does not benefit from any redistribution), equal to $25 / 28 * 57.2 \%=51.1 \%$ (Panel E).

20. A rule such as wage-bill (or wage) growth minus $\beta$ might lead to less than price indexation in some years, leading to lower pensions in real terms which should be avoided. Hence, such a rule should include a floor at price indexation, complemented if activated by a catch-up phase of lower indexation than based on the rule to offset the initial impact of the floor, as Latvia introduced it in 2015 (OECD, 2018a). 
Table 4. Simulations of the generic points system in France

Gross replacement rate (GRR), full career from age 20

\begin{tabular}{|c|c|c|c|c|c|}
\hline \multicolumn{2}{|c|}{$\begin{array}{l}\text { Panel A. Impact of } \\
\text { retirement age }\end{array}$} & \multicolumn{2}{|c|}{$\begin{array}{l}\text { Panel B. Impact of longevity } \\
\text { at the same retirement age }\end{array}$} & \multicolumn{2}{|c|}{$\begin{array}{l}\text { Panel C. Impact of } \\
\text { population growth }\end{array}$} \\
\hline $\begin{array}{l}\text { Retirement } \\
\text { age }\end{array}$ & $\begin{array}{c}G R R, \\
1996 \text { cohort }\end{array}$ & $\begin{array}{c}G R R, \\
1973 \text { cohort }\end{array}$ & $\begin{array}{c}G R R, \\
2019 \text { cohort }\end{array}$ & $\begin{array}{l}\text { annual growth of } \\
\text { 20-64 population }\end{array}$ & $\begin{array}{c}G R R, \\
1996 \text { cohort }\end{array}$ \\
\hline $\begin{array}{l}62 \\
63\end{array}$ & $\begin{array}{l}51.2 \% \\
54.2 \%\end{array}$ & & & $\begin{array}{l}-1 \% \\
-0.5 \%\end{array}$ & $\begin{array}{l}46.7 \% \\
51.9 \%\end{array}$ \\
\hline 64 & $57.2 \%$ & $62.8 \%$ & $52.2 \%$ & $-0.06 \%$ & $57.2 \%$ \\
\hline $\begin{array}{l}65 \\
66 \\
67 \\
68\end{array}$ & $\begin{array}{l}60.2 \% \\
63.3 \% \\
66.6 \% \\
70.2 \%\end{array}$ & & & $\begin{array}{c}0 \% \\
0.5 \% \\
1 \%\end{array}$ & $\begin{array}{l}58.0 \% \\
64.9 \% \\
73.0 \%\end{array}$ \\
\hline
\end{tabular}

Panel D. Impact of indexation of pensions in payments 1996 cohort retiring at age 64

\begin{tabular}{c|c|c} 
& GRR at age 64 & GRR at age 90 \\
\hline$\beta=1.44 \%$ & $\mathbf{5 7 . 2 \%}$ & $41.5 \%$ \\
$\beta=0.19 \%$ & $48.1 \%$ & $48.1 \%$ \\
$\beta=0$ & $46.8 \%$ & $49.1 \%$
\end{tabular}

Panel E. Impact of financing redistribution

Gross replacement rate

\begin{tabular}{l|c|c} 
& $\begin{array}{c}\text { Redistribution } \\
\text { financed by taxes }\end{array}$ & $\begin{array}{c}\text { Contributions of } 3 \text { p.p. } \\
\text { used to finance redistribution }\end{array}$ \\
\hline 1996 cohort & $\mathbf{5 7 . 2 \%}$ & $51.1 \%$
\end{tabular}

Note: Simulations in this table are based on assumptions described in the main text.

116. Employment growth is a critical parameter in PAYGO pension because it directly affects the internal rate of return. It is itself determined by the growth of the working-age population and the change in employment rates. The above simulations are based on a fairly stable working-age population (for France a small decline of $0.06 \%$ per year on average based on Figure 6) and an extrapolation of employment-rate trends over the last two decades adding 0.25 percentage point to the annual growth of the working-age population. However, as shown in Figure 6, there is a wide range in working-age population growth across OECD countries from a large projected decline of $1 \%$ (Latvia) to a large increase of $1 \%$ (Israel). Panel D illustrates the large influence of demographics. Instead of 57.2\% for the baseline number based on French data, the replacement rate would be $46.7 \%$ based on a $1 \%$ average annual decline in the working age to $73.0 \%$ based on a $1 \%$ increase. 


\subsection{Length of the transition and conversion of past entitlements}

117. Table 2 in Section 2 showed that OECD countries which adopted a points or an NDC pension system experienced very different transition paths, from an abrupt transformation in Latvia to a very long transition in Italy. A good compromise for France would be to follow the example of Norway and Sweden. Cohorts five-year younger than the retirement age when the reform was passed were not affected while there was a progressive transition for those being 15-to-20-year younger than the retirement age. Those even younger are covered by the new system only. For example, assuming that the French reform is passed in 2020 and using 62 as the age reference would mean that: cohorts born before 1963 are unaffected; there is a transition for cohorts born between 1963 and 19731978 (depending on the choice made for the length of the transition); and, those born after 1973-1978 are covered by the new system only.

118. COR (2018c) highlighted the key questions raised by such a progressive transition towards a new system. Individuals from the cohorts going through the transition are simultaneously affiliated to both regimes. This means that the old and the new regimes would co-exist during the transition period, with the total benefit being equal to a weighted sum of benefits computed from each scheme. Entitlements must therefore be calculated in both regimes in parallel, before applying the cohort-specific weighting at retirement. Hence, this requires calculating past entitlements in the new scheme for the transition generations as well as for those younger having accumulated some pension rights in the old system.

119. The main difficulty is that the parameters of the new scheme did not exist when the contributions were made. To compute past entitlements in the new scheme, either acquired rights in the old scheme should be converted - the conversion being itself potentially complex - or rights should be granted based on the history of past earnings or past contributions. One issue with the second option might come from the availability of the whole set of past contributions. This might be a serious impediment for some regimes in France (COR, 2018c).

\subsection{Would the reform imply a less redistributive pension system?}

120. A pure point system simply accrues pension entitlements proportionately to contributions actually paid. In such a scheme, there is no redistribution. However, any type of redistributive mechanisms can be added to this generic scheme. These mechanisms can consist of pension credits, survivor pensions, minimum pensions and old-age safety nets among others. This is a matter of political choice. Hence, in practice, the universal points system can be associated with a wide range of redistributive tools.

121. One way to illustrate the relationship or the absence of any relationship between systemic reforms and the amount of redistribution is provided by focusing on survivor pensions, analysed in depth in OECD (2018c). In some countries systemic reforms led to the elimination of survivor protection while in others it had no impact.

122. Sweden eliminated survivor pensions in the public scheme in 1990, almost a decade before the introduction of NDC pensions. In Latvia, as part of the move towards more individualised pension entitlements, survivor pensions for spouses were eliminated when the NDC scheme was introduced in 1996. In Norway, benefit levels had been tightened in 2002 for survivors younger than 55 who do not work. With the introduction of the NDC scheme in 2011, survivor pensions received after the retirement age from the public scheme 
were gradually eliminated, with full effects for the generations born in 1963 and later. There is an ongoing debate in the country about whether survivor pensions after retirement age should be part of the NDC system. In Poland, survivor pensions were almost unaffected by the introduction of NDC, and survivor pensions were not incorporated into the NDC scheme. By contrast, Italy integrated survivor pensions into the NDC design. The introduction of point systems in Estonia, Germany, Lithuania and the Slovak Republic and in 2018 in Lithuania did not affect benefit rules for survivor pensions (OECD, 2018c).

123. However, transparency about redistribution would be improved in the new system. When points are granted for example for periods of unemployment or parental leave, redistribution becomes clearer. This contrasts with the current overall situation in France. Rules are so complex and the system so fragmented that redistribution is often opaque (Bozio et al., 2018). The planned reform is an opportunity to make a collective choice about the forms of redistribution the system should include.

124. The rationale of a points or NDC scheme is also to ensure that the redistributive mechanisms are financed by clearly identified financial resources from general taxation. In theory, redistribution could also be financed by contributions. For example, out the $28 \%$ contribution rate, some percentage points can be used to finance some redistribution mechanisms. ${ }^{21}$ However, the degree to which savings and redistributive components are separated in practice depends on two factors: whether there is a willingness to include redistribution within the contribution pool and whether pension finances are ring-fenced from the other parts of general government budget. For example, in Norway, NDC contributions are paid on total earnings while pension entitlements accrue only up to $115 \%$ of the average wage. By contrast, in Sweden redistribution within the NDC scheme applies through contributions paid from general taxation to individual accounts. Overall, the NDC scheme is much more redistributive in Norway than in Sweden (Marier, 2017).

125. The systemic reform in France also provides a great opportunity to better coordinate first-tier pension instruments, i.e. the minimum pension (minimum contributif) and the oldage safety net (ASPA). Several OECD countries, including Canada, Chile, Denmark and Sweden, better integrate the old-age safety net with the contributory components by smoothly clawing back the non-contributory benefit. In France, these instruments are uncoordinated. In particular, while the age of eligibility for the minimum pension is gradually increasing from 65 to 67 years, in line with the full-pension age, the age required to qualify for ASPA remains unchanged at 65 .

\subsection{Balancing mechanisms}

126. The introduction of automatic links between key pension parameters and variables capturing the main demographic and economic trends has been one major innovation in the pension policy area over recent decades. The objective of these automatic adjustments is to lessen the political pressure to take measures that contribute to financial sustainability. Within the OECD, Denmark, Finland, Italy, the Netherlands, Portugal and the Slovak Republic have linked the retirement age to changes in life expectancy. However, even if those links are legislated this does not mean that political pressure is totally removed; not implementing them might be tempting politically, and the Czech Republic backed off and removed them in 2017.

21. Table 4 shows the result of simulations if 3 percentage points serve this purpose. 
127. Many countries directly link pension benefits with life expectancy (OECD, 2017). First, all funded defined contribution schemes avoid financial sustainability issues by automatically adjusting the level of benefits to changes in longevity through the pricing of annuities. Second, an increase in life expectancy automatically lowers the newly granted pensions in countries with notional defined contribution systems. In addition, as shown above, Italy, Latvia and Poland uprate the notional accounts based on the growth rate of the wage bill or GDP, enabling them to account for the gain or loss of economic potential that might result from changes that affect the size of the labour force. Among NDC countries, Norway does not include such a mechanism while Sweden designed an automatic balancing mechanism which is discussed below. Third, Finland, Japan and Spain (sustainability factor) have introduced similar mechanisms linked to changes in life expectancy in their DB pensions. Fourth, in Germany, Japan and Portugal, there is an automatic adjustment of pensions to changes in the ratio of the number of workers per pensioner.

128. One central issue for the management of public PAYGO pension systems, and of points and NDC schemes in particular, refers to how pension accounts are clearly separated or even ring-fenced from the other components of general government balances. Are pension entitlement rules (points, NDC, etc.) just a technical device used to compute pension benefits and possibly improve transparency, or are they designed to ensure financial sustainability and managed along with earmarked revenues in clearly separated accounts to achieve a cumulative balance over time?

129. Sweden is the only country which directly adjusts pension entitlements and benefits to ensure solvency, based on current pension liabilities and assets made of contribution assets and (the market value of) the buffer fund. The buffer fund represents around $30 \%$ of GDP and $10-15 \%$ of total pension assets, although these shares have been volatile as explained below. An automatic balancing mechanism is applied when the calculations imply a potential deficit. In that case, a brake is activated, as it first was in 2010 based on 2008 values, reducing the notional interest rate below the wage growth rate in order to both limit accumulation in notional accounts and reduce indexation of pensions in payments so as to restore solvency. When rebalancing is achieved, any surplus can be used to boost the interest and indexation rates during a catch-up phase. By contrast, there is no balancing mechanism in Norway, and the general government budget backed by the national wealth fund remains the shock absorber (Section 2).

130. Auerbach and Lee (2009) highlight the asymmetric design of the Swedish mechanism, which explains why it is often referred to as a brake as it might reduce total rates of return but never raises them, thereby potentially leading to the accumulation of surpluses over time. Barr and Diamond (2011) show that under certain conditions the brake mechanism triggers a sharp adjustment at the expense of retirees relative to workers. They make proposals to better share the burden and smooth the impact of the balancing mechanism.

131. Within its points scheme, Germany introduced an automatic adjustment mechanism (Box 1). Employment and demographic trends affect the point value through the sustainability factor. One specificity of the German rule refers to the additional role played by adjusting the contribution rate, which does not affect the number of points in the German pension system. The contribution rate must be increased if the pension account balance deteriorates beyond a certain threshold, which in turn automatically lowers the point value, thereby sharing the burden of the adjustment between current workers and current pensioners. One significant difference with the Swedish mechanism is that the adjustment 
is triggered based on short-term liquidity imbalances and not on the estimated solvency rate. In Germany, there are ceilings in the allowed contribution rate until 2030 but in the long-term the way the point value is adjusted to the old-age dependency ratio alone in order to maintain financial balances might not be sufficient to prevent contribution rates from rising beyond acceptable levels.

132. The extent to which aggregated pension accounts are financially isolated from general government budget is a crucial decision to make. The introduction of an automatic balancing mechanism imposes a strict discipline in financial management. What is gained from this loss in flexibility is greater confidence in the system, more credibility as solvency is guaranteed in a more transparent manner (Holzmann, 2017), and less political, discretionary interference. Given the double challenge France faces to unify the current very diverse pension landscape and adopt a universal points system, a strict separation of accounts, even though it is a commendable long-term objective, might not be part of shortterm priorities. In Sweden, the legislation providing the automatic balance mechanism was adopted in 2001, i.e. three years after the NDC reform passed. Yet, assessing the solvency of the system remains critical even in the absence of a balancing mechanism.

133. The system could be unbalanced due to long-term developments affecting wages, employment or life expectancy, and also because of short-term shocks. A large part of these imbalances can be eliminated or at least substantially reduced by ensuring that the parameters of the points or NDC scheme are closely aligned with internal rates of return of PAYGO schemes so as to strengthen resilience to economic and demographic trends. That is, with wage-bill growth while accounting for changes in life expectancy as discussed in section 4.3 about the generic points system.

134. In Sweden and Norway for example, the notional interest rate is the growth rate in average wages rather than in total wages (wage bill), making finances sensitive to employment shocks such as recently experienced during the Great Recession. This choice of the interest rate reinforces the need of a balancing mechanism. In Germany as well, by design the points scheme does not feature the point-cost concept, which has the following implication (Section 2): past wages are implicitly uprated in line with wage growth, creating a wedge with internal rates of return as employment growth is not accounted for. This is a source of cyclical and structural imbalances. The adjustment rule (Box 1) only partly corrects for these imbalances, and federal subsidies are needed in addition to fully offset the impact of demographic and employment trends.

135. Likewise, countries which index pensions at least partly to prices create a source of imbalances. Another source of financial vulnerability appears in countries such as Estonia, Lithuania or the Slovak Republic, which do not account for changes in life expectancy. However, even in countries which do, mortality rates are likely to end up being different from their expected values when initial benefits are computed, generating mismatches. Hence, even when rules are designed to minimise these sources of imbalances from emerging and when mortality rates are correctly projected, financial balances cannot be ensured at all points in time under any circumstances.

136. A balancing mechanism is thus a valuable tool, but even Sweden experienced some difficulties in applying the brake rule during the Great Recession. In that sense, the economic and financial turmoil provided a stress test for the automatic adjustment rules. The adjustment implied by the rule would have amounted to a real-term reduction of $4.6 \%$ in pensions (Sundén, 2009), and was considered so large that the rule was altered. 
137. Two main reasons explain why the needed adjustment was large. First, as discussed above, the Swedish NDC rules do not directly account for changes in employment. Employments shocks affect PAYGO finances nevertheless, and in Sweden the impact materialises through the brake rule. Second, this effect was magnified by the huge drop in stock markets, which led to a sharp fall of more than $20 \%$ in the value of the buffer fund in 2008. While the size of the buffer fund plays an important role to ensure long-term sustainability, it makes the NDC scheme sensitive to financial-market performance. In response, policymakers decided to smooth the market value of the buffer fund over a threeyear period and spread out the required adjustment over a longer period (Sundén, 2009).

138. Overall, while the Swedish mechanism was put to the test by the Great Recession, it proved resilient, only requiring a small adjustment. As a result its broad principles remain largely unchallenged even though the experience shows that in periods of large volatility interventions by politicians are still needed (Weaver and Willén, 2014).

\section{Box 4.1. The mechanics of the German points system}

For every year of work, a person earns points based on her individual gross annual earnings. One point is granted to an individual whose earnings equal the average earnings in Germany in the same year. Lower and higher individual earnings up to a ceiling generate proportionally more and less points, respectively, based on the principle of equivalence between contributions and benefits (Äquivalenzprinzip). Very low temporary monthly incomes of 450 euros or less and incomes exceeding the ceiling, which lies at about $215 \%$ of average earnings, are exempt from social security contributions and do not earn pension entitlements. Reduced social security contributions and pension entitlements apply in case of earnings up to a monthly average of 1,300 euros. Additional points are granted for childcare periods and when receiving unemployment benefits. A penalty/bonus factor applies for early/late retirement before/after the normal retirement age.

The point value is adjusted every year on 1 July based on below formula for the adjustment factor (AF). Demographic and economic changes are accounted for through three parts: growth in gross average earnings, growth in the contribution rate, and a sustainability factor. A time lag of 1 year is used for practical reasons.

$A F_{\mathrm{t}} \equiv \frac{\text { pension point value }_{t}}{\text { pension point value }_{\mathrm{t}-1}}=\frac{\text { average earnings }_{\mathrm{t}-1}}{\text { average earning } \mathrm{s}_{\mathrm{t}-2}} \cdot \frac{100-\text { contribution rate }_{t-1}}{100-\text { contribution rate }_{\mathrm{t}-2}} \cdot \overbrace{\left(1-0.25 \cdot \frac{P C R_{t-1}-P C R_{t-2}}{P C R_{\mathrm{t}-2}}\right)}^{\text {Sustainability factor }}$ where PCR is the pensioners to contributors ratio (see below).

In addition, an increase (decline) in the contribution rate has to be legislated once the account balance managed by the public pension authority drops below (exceeds) a certain level. The contribution-rate component of the adaptation factor implies that the benefit level declines when the contribution rate increases and vice versa. This makes current contributors and pensioners suffer or benefit jointly from current financial developments, for example driven by a deteriorating or an improving labour market. Since the introduction of tax subsidies for voluntary private pensions (Riester pensions) in 2001, the contribution- 
rate factor includes the maximum voluntary contribution rate that is subsidised, which is currently equal to $4 \%$.

The third factor was introduced in 2004 to help deal with financial sustainability. It is determined by changes in the ratio of pensioners to contributors. An increase in the pensioners-to-contributors ratio means that the point value is not fully indexed to earnings growth. An increase of $1 \%$ in the relative number of pensioners decreases the point value by $0.25 \%$. The 0.25 factor was determined to fulfil the objective of ensuring that the contribution rate remains below $22 \%$ by 2030 and is not scheduled to be changed. Rather than the straightforward number of contributors and pensioners, a rather complex calculation is applied to derive the number of equivalised standard contributors earning the average wage and standard pensioners with 45 pension points. Overall, the sustainability factor is meant to capture the demographic and labour market developments that affect the financial sustainability of the system.

An adjustment factor below the inflation rate (plus 1), which implies a decline in the real value of pensions, is allowed and also intended if, for example, demographic change deteriorates the ratio of contributors to pensioners. Nominal declines of the pension point value are ruled out by a restrictive clause but have to be offset in following years by a lower indexation than implied by the adjustment factor. This happened in 2005, 2006 and 2010 where the adjustment factor was lower than one. A law passed at the end of 2018 introduces a floor in the pension point value such that the net replacement rate of an average-wage worker with a 45 -year career is at least $48 \%$ until 2025 . That law also imposes a ceiling of $20 \%$ on the contribution rate until 2025 (Doppelte Haltelinie). Yet population ageing is expected to have its largest impact after 2025 as the so-called old-age dependency ratio is projected to accelerate sharply between around 2025 and 2035.

\section{Conclusion}

139. The planned systemic pension reform in France is very important. The current system provides effective social protection for current retirees, but it is overly complex. Differences across schemes fuel the suspicion that workers covered by other schemes might be better treated. Not only does the co-existence of 42 regimes generate unequal treatment of different population groups, the coordination of such a large number of different schemes also leads to complications. While challenging, unifying the rules used to compute benefits would therefore shape an improved pension landscape for decades to come. Moreover, successive reforms of the different schemes bear political costs and only have partial impacts, thereby feeding reform fatigue. They are also at risk of being unintentionally inequitable due to the overall opacity of the system. Reducing the complexity of the French system to enhance economic performance is the prime goal of the reform.

140. This reform should be taken as an opportunity to eliminate some of the shortcomings of the current system, including the sensitivity of replacement rates and pension finances to long-term productivity growth, unintended forms of redistribution due to the complex interaction of rules and the fact that only parts of the career are taken into account to calculate pension entitlements. France is one of only few OECD countries, along with Slovenia, Spain and the United States, which do not take account of the entire earnings history. 
141. NDC or points techniques provide an attractive and transparent setting for PAYGO pensions. France opted for a points system. The main advantages of a well-defined NDC scheme is its embedded robustness to economic and demographic shocks in the long term. However, workers might find it difficult to grasp the concept of notional accounts. Points are simpler, and French workers are more familiar with them as Agirc and Arrco schemes have been operating based on points at a large scale for about half a century. Yet, beyond the technique to compute benefits that is inherent to points, points systems can differ widely depending on whether they are managed discretionarily such as the Agirc-Arrco scheme or based on rules closely related to the generic points system discussed in section 4 . It is therefore important that the points system be designed to as much as possible automatically adjust to various trends and shocks, in particular those affecting demography and the labour market.

142. Indexation rules should be defined in a way that helps achieve the maximum rates of return on pension contributions while ensuring financial sustainability - i.e. the internal rate of return which in PAYGO schemes is the growth rate of the contribution base (or the wage bill with stable contribution rates) - and accounting for changes in life expectancy. When employment and demographic trends are not properly accounted for, there are two broad alternatives. Either the general government balance can act as the shock absorber, as in Norway. Or complex adjustment mechanisms can be put in place, such as in Germany and Sweden, to correct for this limitation. Of course, even when rules are designed to minimise sources of imbalances, financial balances cannot be ensured at all points in time under any circumstances. Some adjustments are always needed, for example given that ex post mortality rates differ from their projected values used to convert accumulated points into a stream of pension benefits when retiring.

143. The technical analysis herein shows how such rules can be designed. The cost of points would be indexed to wage-bill growth, and the value of points, at the same age from one generation to the next, to wage-bill growth minus the growth rate in remaining life expectancy, which is currently projected to be close to $0.4 \%$ per year in France. According to current projections of the working-age population, it might make little difference in France to use the growth rate of wages rather than of the wage bill. However, this would expose the financial balance to unexpected employment trends.

144. Overall, the implication would be that the value of the point should vary at the individual level depending on the cohort and the effective age of retirement based on actuarial principles to take into account remaining life expectancy. One advantage is that two individuals of different ages retiring in the same year (therefore of different birth cohorts) and having accumulated the same number of points (therefore based on similar total contributions) - for example because the older person had lower earnings or a more interrupted career - would not have the same pension benefit: indeed, in that case the older person, being expected to have a shorter retirement period, should benefit from a higher pension.

145. This age-cohort schedule can be introduced with point-value tables by age and cohort. An alternative way would be to: define a retirement-age reference (âge-pivot de depart à la retraite) with a cohort-specific point value; apply a bonus-penalty scheme; and, index the point value across cohorts at the age reference as discussed above to take into 
account changes in life expectancy. ${ }^{22}$ No country currently uses age-cohort point values, and France could be the first one to introduce this innovation. Accumulated points would then be converted into euros when retiring and indexed during retirement.

146. There is flexibility in the choice of the indexation rule. The generic points system is based on indexing to wage-bill growth minus a given parameter. The choice of this parameter is a political decision. The less generous the indexation the higher the initial pension and the lower the pension later in retirement. Hence, a high value of this parameter will mean a less generous indexation and a higher initial pension, benefiting those who die early, thereby reducing the impact of inequality in life expectancy.

147. In terms of the length of the transition from the old to the new system, a good compromise for France would be to follow the example of Norway and Sweden. Cohorts about five years younger than the retirement age when the reform was passed were not affected while there was a progressive transition for those being 15 (or 20) years younger than the statutory retirement age. For example, if the reform is legislated in 2020, this could mean that those born before 1963 (who will be older than 62 in 2025) are unaffected by the reform, that there is a smooth transition for those born between 1963 and 1972, and that the cohorts born in or after 1973 will be covered by the new system only. This would imply calculating entitlements in the old and new system in parallel during the transition and applying a cohort-specific weighting at retirement. Estimating precisely past entitlements in the new system for the transition generations and those younger who acquired rights in the old system requires a full history of earnings or contributions, which might not be available in some regimes in France.

148. One important question is whether the unified framework would reduce the redistributive capacity of the system. At its core, the tight link between contributions and benefits implies no redistribution in the generic points system. Numerous analyses done by the French Pension Advisory Council showed that the core of the current French system is actually regressive. The new universal points system can actually be associated with a wide range of redistributive tools, depending on political choices. The main advantage of the new system is that transparency about redistribution and its sources of financing would be substantially improved. One key political decision is whether redistributive instruments should be entirely financed by general taxation or at least partly by a share of total contributions.

149. One central issue refers to the extent to which pension accounts are separated or even ring-fenced from the other components of general government balances. Sweden is the only country which directly adjusts pension entitlements and benefits to ensure solvency, based on current pension assets and liabilities. A strict separation of accounts is a commendable long-term objective. However, given the double challenge France faces to unify the very diverse pension landscape and adopt a universal points system, it is probably not part of today's short-term priorities. However, assessing how financially sustainable the system is, based on independent long-term projections of pension assets and liabilities, remains crucial.

150. Neither raising effective retirement ages nor lowering pension expenditures more generally are among the direct objectives of the ongoing pension reform. This makes sense

22. Bonus-penalty schemes provide both flexibility in terms of retirement ages and incentives to work longer while, if well-defined, avoiding that early-retirement decisions weigh on the pension budget. In order to influence behaviours about working at older ages, it might be helpful to define as a reference a retirement age (âge-pivot) providing eligibility to a full pension. 
because attention should focus on reducing complexity and not be dispersed in trying to fix other issues. At the same time, labour market exit ages are low and a minimum retirement age of 62 will not be consistent with increasing longevity over time and the need to promote employment of older workers. Hence, in the long term, the minimum retirement age will need to increase in line with life expectancy gains. 


\section{References}

Aubert P. and C. Duc (2011), "Les conséquences des profils individuels des revenus d'activité au long de la carrière", Economie et Statistique, No 441-442.

Auerbach, A.J. and R. Lee (2009), "Notional Defined Contribution Pension Systems in a Stochastic Context: Design and Stability". In Social Security Policy in a Changing Environment, J. Brown, J. Liebman, and D.Wise, eds.

Barr, N. and P. Diamond (2011), "Improving Sweden's automatic pension adjustment mechanism", Center for Retirement Research at Boston College, Number 11-2.

Bernheim, B. D., J. Skinner and S. Weinberg (2001), "What Accounts for the Variation in Retirement Wealth among U.S. Households ?", American Economic Review, 91 (4).

Boeri, T., P. Garibaldi and E. Moen (2016), "A clash of generations? Increase in Retirement Age and Labor Demand for Youth", Centre for Economic Policy Research.

Bozio, A., S. Rabaté, A. Rain and M. Tô (2018), "Quelle réforme du système de retraite? Les grands enjeux », Les Notes de l'IPP, No 31.

Chłoń-Domińczak, A., D. Franco and E. Palmer (2013), “The First Wave of NDC Reforms: The Experiences of Italy, Latvia, Poland, and Sweden”, in R. Holzmann, E. Palmer and D. Robalino, eds.

Christensen, A.M., D. Fredriksen, O.L. Lien and N.M. Stolen (2012), "Pension Reform in Norway: Combining an NDC Approach and Distribution Goals", In R. Holzmann, E. Palmer and D. Robalino, eds.

COR (2018a), Rapport annuel, Conseil d'orientation des retraites, Paris.

COR (2018b), "Pilotage du système de retraite", Documents No 2 et 5 , Séance plénière du 18 octobre 2018, Secrétariat général du Conseil d'orientation des retraites.

COR (2018c), "La transition vers un nouveau régime de retraite", Document No 8, Séance plénière du 14 février 2018, Secrétariat général du Conseil d'orientation des retraites.

DGAFP (2018), Rapport annuel sur l'état de la fonction publique, Ministère de l'action et des comptes publics.

Franco, D. and N. Sartor (2006), "NDCs in Italy: Unsatisfactory Present, Uncertain Future", In R. Holzmann and E. Palmer, eds.

Guardiancich, I.R., K. Weaver, G. Demarco and M. Dorfman (2019), "The Politics of NDC Pension System Diffusion: An Idea Whose Time Has Come and Gone?", In R. Holzmann, E. Palmer, R. Palacios and S. Sacchi, eds.

Fredriksen, D, E. Holmoy, B. Strom and N.M. Stolen (2019), "Fiscal effects of the Norwegain pension reform - A micro-macro assessment", Journal of Pension Economics and Finance, Vol. 18 (1).

Holzmann, R. (2017), “The ABCs of Nonfinancal Defined Contribution (NDC) Schemes", IZA Policy Paper, No 130.

Könberg, B. E. Palmer and A. Sundén (2006), "The NDC Reform in Sweden: the 1994 Legislation to the Present", Chapter 17.

Kudrna, G. (2017), "The Norwegian Pension Reform: An External Perspective", CEPAR Working Paper 2017/07. 
Lesay, I. (2006), Pension reform in Slovakia: the context of economic globalisation, European Trade Union Institute for Research, Education and Health and Safety (ETUIREHS).

Marier, P. (2017), "The politics of policy adoption: a saga on the difficulties of enacting policy diffusion or transfer across industrialised countries", Political Science, No 50.

OECD (2018a), OECD Reviews of Pension Systems: Latvia, OECD Publishing, Paris.

OECD (2018b), OECD Reviews of Labour Market and Social Policies: Lithuania, OECD Publishing, Paris.

OECD (2018c), “Are survivor pensions still needed?”, Pensions Outlook, Chapter 7, OECD Publishing, Paris.

OECD (2017), Pensions at a Glance, OECD Publishing, Paris.

OECD (2016), "Civil service pension: Toward a unified system with the private sector", Pensions Outlook, Chapter 6, OECD Publishing, Paris.

OECD (2005), Pensions at a Glance, OECD Publishing, Paris.

OECD (1999), The Tax/Benefit Position of Employees: 19971998 Edition, OECD Publishing, Paris.

Queisser, M. and E. Whitehouse (2006), "Neutral or Fair? Actuarial Concepts and PensionSystem Design", OECD Social, Employment and Migration Working Papers, No. 40.

Raudla, R. and K. Staehr (2003), "Pension Reforms and Taxation in Estonia", Baltic Journal of Economics, Vol. 4/1.

Schmäl, W. (1993), "The 1992 Reform of Public Pensions in Germany: Main Elements and some Effects", Journal of European Social Policy, January.

Schoyen, M. and F. Stamati (2013), "The Political Sustainability of the NDC Pension Model: The Cases of Sweden and Italy", European Journal of Social Security, Vol. 15/1.

Settergren, O. (2003), "The Reform of the Swedish Pension System - Initial Results", RFAS 2003(4).

Steffen, J. (2002), "Die Anpassung der Renten in der Rentenversicherung der Arbeiter und Angestellten - Von der Rentenreform 1957 bis zum AVmEG", mimeo.

Sundén, A. (2009), "The Swedish pension system and the economic crisis", Center for Retirement Research at Boston College, Number 9-25.

Sundén, A. (2013), "The Challenge of Reaching Participants with the Message of NDC", in R. Holzmann, E. Palmer and D. Robalino, eds. Chapter 17.

Weaver, K. and A. Willén (2014), "The Swedish pension system after twenty years: Midcourse corrections and lessons", OECD Journal on Budgeting, Vol. 2013/2.

World Bank (1994), Averting the old age crisis : policies to protect the old and promote growth, World Bank, Washington DC. 